\title{
$\mathrm{ADB}$
}

\section{СТРАТЕГИЯ 2030}

Создание процветающего, инклюзивного, жизнестойкого и устойчивого Азиатско-Тихоокеанского региона

ИЮЛь, 2018

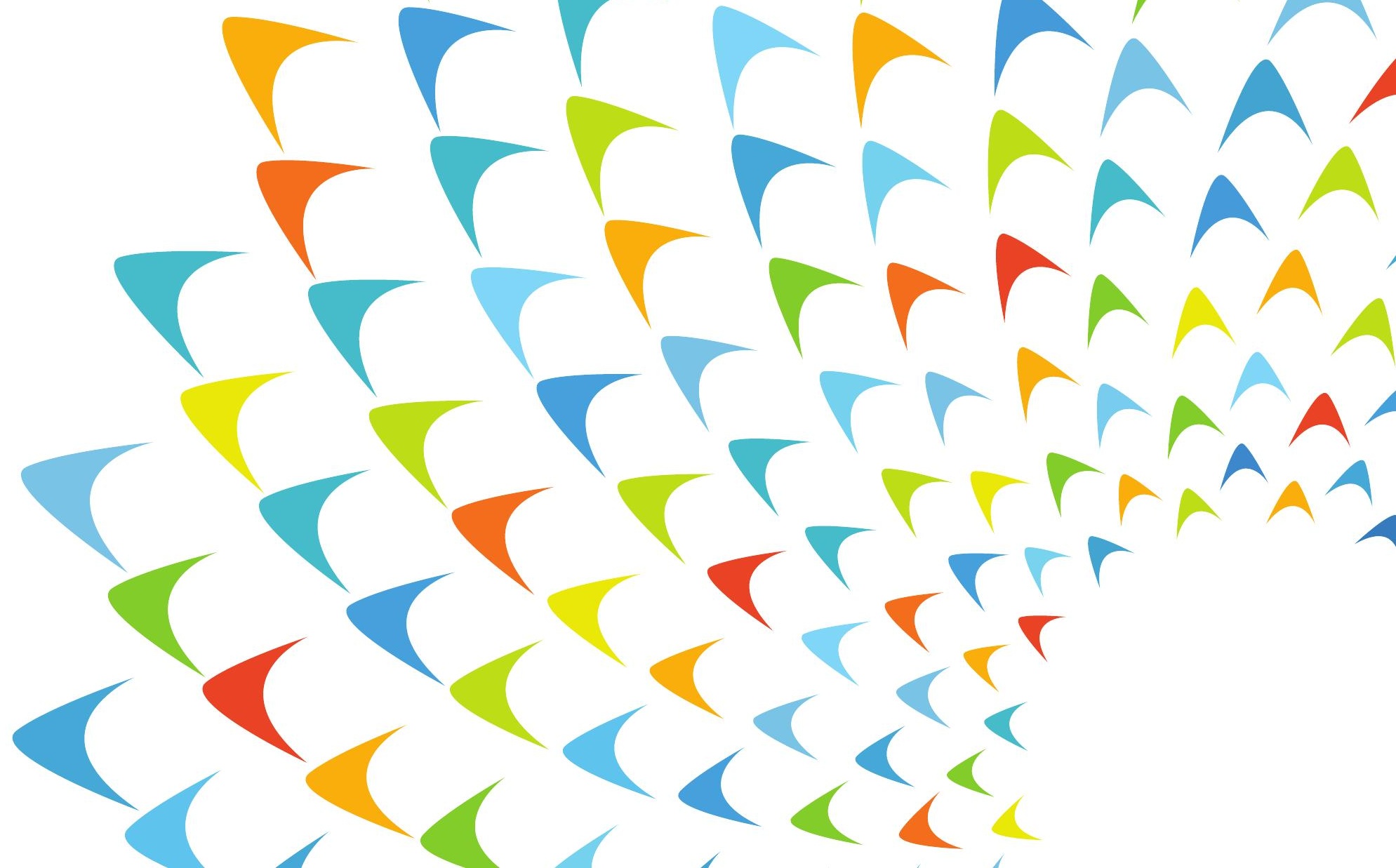


ВИДЕНИЕ СТРАТЕГИИ 2030

ПРОЦВЕТАЮЩИЙ ИНКЛЮзИВНЫЙ ЖИЗНЕСТОЙКИЙ УСТОЙЧИВЫЙ

АЗИАТСКО-ТИХООКЕАНСКИЙ РЕГИОН

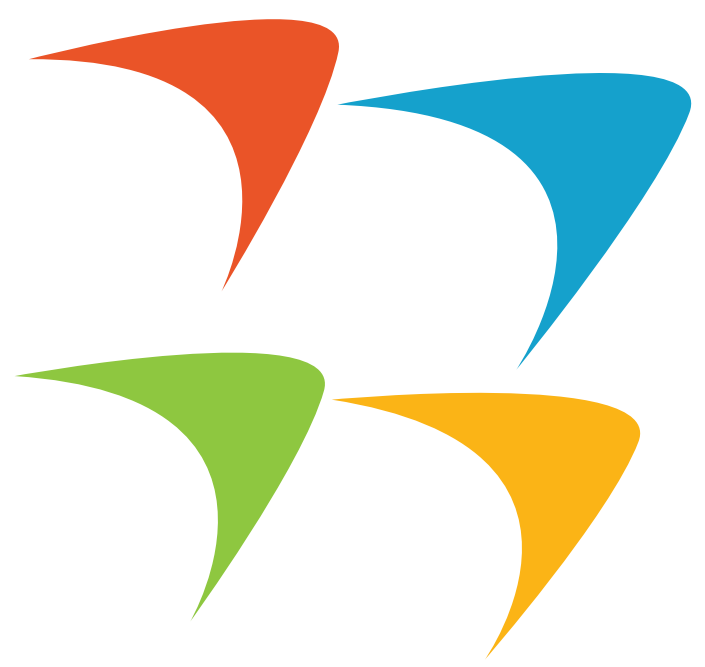




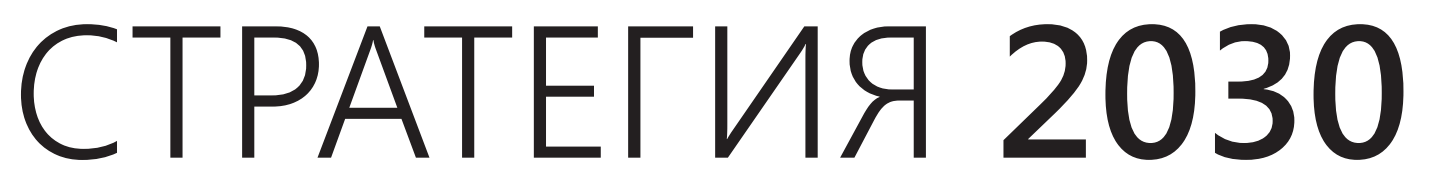

Создание процветающего, инклюзивного, жизнестойкого и устойчивого Азиатско-Тихоокеанского региона

ИЮЛЬ, 2018 
(C) 2018 Asian Development Bank

6 ADB Avenue, Mandaluyong City, 1550 Metro Manila, Philippines

Tel +632632 4444; Fax +6326362444

www.adb.org

Все права защищены. Опубликовано в 2018 г.

ISBN 978-92-9261-390-7 (print), 978-92-9261-391-4 (electronic)

Номенклатурный номер публикации No. TCS189471-3

DOI: http://dx.doi.org/10.22617/TCS189471-3

АБР не гарантирует точность данных в настоящей публикации и не несет никакой ответственности за последствия их использования. Упоминание конкретных компаний или определенной продукции производителей не означает, что АБР одобряет или рекомендует их, отдавая им предпочтение перед другими компаниями или продуктами аналогичного характера, не упомянутыми в публикации.

Обозначения или ссылки на конкретную территорию или географический регион, а также использование термина "страна" в настоящем документе не являются выражением мнения АБР относительно правового или иного статуса какой-либо территории или какого-либо региона.

АБР приветствует распечатку или копирование информации исключительно для личных, образовательных и некоммерческих целей при надлежащей ссылке на АБР. Пользователям запрещается продавать, распространять или создавать материалы на основе данного документа в коммерческих целях без письменного согласия АБР. В случае возникновения вопросов или комментариев по содержанию, для получения разрешения от обладателя авторского права просим связаться по электронному адресу: pubsmarketing@adb.org.

Примечания:

В данной публикации символом "\$" обозначены доллары США

АБР указывает "Китай", имея в виду Китайскую Народную Республику, и "Корея" - Республику Корея. С исправленными опечатками в публикациях АБР можно ознакомиться по ссылке: http://www.adb.org/ publications/corrigenda.

1 Напечатано на бумаге из вторичного сырья.

Настоящий документ переведен с английского языка для охвата более широкой аудитории читателей. Английский язык является официальным языком Азиатского банка развития (АБР), и несмотря на предпринятые АБР усилия для проверки точности перевода, оригинал данного документа на английском языке - это его единственная официальная и юридически правомочная версия. При цитировании необходимо давать ссылку на оригинал.

\section{Изображение на обложке: числа Фибоначчи}

Фибоначчи - это средневековый математик, который ввел последовательность чисел, при которой каждое число является суммой двух предыдущих чисел: 0, 1, 1, 2, 3, 5, 8, 13, и т.д. Такая числовая последовательность встречается в природе, например, в расположении листьев вокруг стебля.

В основе концепции Стратегии 2030 лежит последовательность чисел Фибоначчи. Концепция представляет продуманный и динамичный новый курс деятельности АБР, обозначенный до 2030 года. 


\section{СОДЕРЖАНИЕ}

Аббревиатуры iv

Резюме $\quad \mathrm{V}$

I. Введение 1

II. Меняющийся ландшафт и вызовы 3

$\begin{array}{ll}\text { III. } & 10\end{array}$

IV. Руководящие принципы осуществления операций АБР 13

V. Дифференцированные подходы к группам стран 14

VI. Операционные приоритеты 17

VII. Расширение операций в частном секторе 24

VIII. Стимулирование и привлечение средств на развитие 27

IX. Улучшение услуг по передаче знаний 30

Х. АБР стремится стать сильнее, лучше и быстрее 32

XI. Один АБР 35

Приложение: Обзор операций АБР и резюме итогов 36 консультационных совещаний 


\title{
АББРЕВИАТУРЫ
}

\author{
АБР Азиатский банк развития \\ АФР Азиатский фонд развития \\ АCЕАН Ассоциация государств Юго-Восточной Азии \\ СПС Страновая стратегия партнерства \\ ОГО Организации гражданского общества \\ ОЭР Обзор эффективности развития \\ РС4 Развивающаяся страна-член \\ ФАО Продовольственная и сельскохозяйственная организация $\mathrm{OOH}$ \\ FCAC Нестабильные и затронутые конфликтами страны \\ ПГ П Парниковые газы \\ ИКТ Информационно-коммуникационные технологии \\ ДНО Департамент независимой оценки \\ ЛНДР Лаосккая Народно-Демократическая Республика \\ ООР Обычные основные ресурсы \\ PBL Кредитование в поддержку реформ \\ ГЧП Государственно-частное партнерство \\ КНР Китайская Народная Республика \\ РСИ Региональное сотрудничество и интеграция \\ ЦУР Ц Цели устойчивого развития \\ SIDS Малые островные развивающиеся государства \\ МСП Малые и средние предприятия \\ ГП Государственное предприятие \\ ТП Техническая помощь \\ UMIC Страна с уровнем дохода выше среднего \\ ЮНИСЕФ Детский фонд ООН \\ ВПП Всемирная продовольственная программа \\ BO3 Всемирная организация здравоохранения
}




\section{PEЗЮME $>7$}

За последние 50 лет Азиатско-Тихоокеанский регион добился впечатляющего прогресса в сокращении бедности и ускорении экономического роста. Однако, в регионе по-прежнему имеются такие нерешенные вопросы в области развития, как бедность и уязвимость, усиление неравенства, последствия изменения климата, растущее давление на окружающую среду и огромный дефицит в инфраструктуре. Новейшие тенденции, такие, как технологические разработки, урбанизация и демографические изменения, содержат в себе как возможности, так и вызовы.

Учитывая размер Азиатско-Тихоокеанского региона, выполнение таких масштабных глобальных обязательств как Цели устойчивого развития, Программа финансирования развития, Парижское соглашение по изменению климата и Сендайская рамочная программа по снижению риска бедствий, будет в решающей степени зависеть от успешного развития данного региона.

Курс деятельности Азиатского банка развития (АБР), обозначенный в Стратегии 2030, направлен на эффективное реагирование на меняющиеся потребности региона. В Стратегии отмечается, что АБР расширяет свое видение создания процветающего, инклюзивного, жизнестойкого и устойчивого Азиатско-Тихоокеанского региона, не прекращая при этом постоянных усилий, направленных на искоренение крайней нищеты. Цели АБР согласуются с основными глобальными обязательствами

АБР будет играть важную роль в осуществлении всемирной программы развития инфраструктуры как источника глобального роста. Инфраструктурные проекты останутся ключевым приоритетом в социальноэкономическом развитии региона. АБР будет оказывать содействие в привлечении инвестиций в повышение качества инфраструктуры, в частности в создание экологически безопасной, устойчивой, инклюзивной и надежной инфраструктуры. Наряду с этим, АБР расширяет участие в таких социальных секторах, как образование, здравоохранение и социальная защита. АБР будет также стремиться к использованию своих экспертных зна- ний и опыта по всем секторам и направлениям для решения более сложных задач в области развития.

Как надежный партнер в области развития, АБР окажет ценное содействие своим членам - развивающимся странам (РСЧ), совмещая финансирование с передачей знаний и партнерскими проектами. АБР и впредь будет надежным источником и катализатором финансирования. В области передачи знаний АБР сосредоточит внимание на их практической ценности для местных условий, проанализирует полученные уроки и распространит передовые практики внутри региона и за его пределами. В качестве координатора партнерских проектов, АБР будет продвигать диалог и сотрудничество с различными партнерами и заинтересованными сторонами и будет стремиться к оптимизации деятельности международных финансовых институтов в целом. АБР также усилит свою роль в качестве разработчика проектов.

Амбициозная глобальная повестка развития должна быть адаптирована к специфическим местным условиям. АБР будет укреплять страновой подход, используя страновые стратегии партнерства как основные платформы для выработки адаптированного подхода, продвижения инновационных технологий и комплексных мероприятий, сочетая экспертные знания из различных отраслей и сфер и реализуя их через проекты в государственном и частном секторах. На уровне стран АБР будет действовать избирательно, опираясь на свои сравнительные преимущества, потребности конкретной страны и потенциал для повышения эффективности в рамках тех возможностей и ресурсов, которые имеются у АБР для реализации конкретного круга задач.

С учетом значительных различий между странами в современном мире АБР будет применять дифференцированный подход на уровне различных групп стран. В первую очередь, поддержка будет оказана беднейшим и наиболее уязвимым странам в регионе, в том числе нестабильным и затронутым конфликтами, а также малым островным развивающимся государствам. АБР адаптирует бизнес-процессы применительно к этим 
странам, усилит в них кадровые ресурсы и свое присутствие на местах. Это обеспечит прогнозируемое и существенное долгосрочное финансирование для поддержки стран с низким и ниже среднего уровнями доходов. В странах с уровнем доходов выше среднего АБР сосредоточит поддержку в тех областях, в которых может принести наибольшую пользу. В этих группах стран АБР будет уделять первоочередное внимание отстающим направлениям развития и районам сосредоточения бедности и нестабильности.

АБР будет применять действующую политику завершения деятельности, одновременно анализируя ее эффективность. Отход от регулярной помощи АБР будет проводиться в тесном сотрудничестве с правительством страны, анализируя и оценивая при этом ключевые элементы политики завершения работы в данной стране. Применяя дифференцированный подход, АБР проведет подробный анализ и обсудит с различными заинтересованными сторонами возможность диверсификации условий финансирования своих продуктов и инструментов. АБР направит льготное финансирование наиболее бедным и уязвимым странам-членам и рассмотрит возможности оказания дополнительной помощи тем странам, для которых льготное финансирование прекращено.

Поддержка АБР (включая опреации в государственном и частном секторах, консультационные услуги и передачу знаний) будет сосредоточена на следующих основных направлениях деятельности.

i. Устранение сохраняющейся бедности и снижение неравенства. Для искоренения бедности, не связанной с доходами, АБР будет уделять больше внимания развитию человеческого потенциала и социальной интеграции, что будет способствовать созданию качественных рабочих мест, в том числе в малых и средних предприятиях и в инклюзивном бизнесе. АБР будет оказывать помощь РСЧ в улучшении систем образования и обучения, всеобщего здравоохранения и социальной защиты и повышении качества услуг нуждающимся группам населения.

ii. Ускорение прогресса в обеспечении гендерного равенства. АБР будет поддерживать целевые операции по расширению прав и возможностей женщин и девочек, внедрению гендерного подхода, что напрямую сокращает гендерные разрывы, а также осуществлять операции с учетом гендерных вопросов, которые включают в себя реализацию отдельных мер обеспечения гендерного равенства при разработке и осуществлении проектов и программ АБР. Как минимум, 75\% совершенных операций АБР (на основе скользящей средней величины за три года, включая суверенные и несуверенные операции) будут способствовать достижению гендерного равенства к 2030 году.

iii. Борьба с последствиями изменения климата, формирование устойчивости к последствиям изменения климата и стихийных бедствий и повышение экологической устойчивости. АБР существенно расширяет помощь в этих сферах и обеспечит, чтобы 75\% совершенных операций (по скользящей средней величине в течение 3-х лет, включая суверенные и несуверенные операции) способствовали смягчению последствий изменения климата и реализации мер адаптации к 2030 году. Объем финансирования этого направления из собственных средств АБР в период с 2019 по 2030 годы достигнет \$80 млрд.

iv. Улучшить условия жизни в городах. АБР предоставит комплексные решения для создания более удобных условий жизни в городах и преобразованию их в экологически безопасные, конкурентные, устойчивые и интегрированные места проживания. Будут реализованы сквозные проекты в области здравоохранения в городах, мобильности городского населения, по гендерному равенству и экологической устойчивости. АБР окажет помощь в освоении новых и расширении существующих источников финансирования для городов, повышении инклюзивного и совместного городского планирования и внедрении мер управления рисками стихийных бедствий и противодействии последствиям изменения климата в процессы городского планирования.

v. Содействие развитию сельской местности и обеспечению продовольственной безопасности. АБР будет поддерживать усилия по улучшению 
рыночных связей и производственно-сбытовых цепочек в сельском хозяйстве, что поможет РСЧ повысить производительность сельского хозяйства и укрепить продовольственную безопасность за счет увеличения фермерских и нефермерских доходов, продвижения передовых технологий и агрономической практики, не причиняющей ущерб климату, а также поддержки совершенствования стандартов управления природными ресурсами. Кроме того, эти меры будут способствовать укреплению продовольственной безопасности в PC4.

vi. Совершенствование управления и развитие институционального потенциала. АБР окажет поддержку в осуществлении реформ государственного управления в РСЧ в целях совершенствования управления и создания благоприятных условий для устойчивого роста. АБР внесет вклад в повышение сопротивляемости и готовности стран к экономическим потрясениям, улучшение качества услуг и стандартов, а также развитие потенциала. АБР обеспечит соблюдение экологических и социальных защитных мер, будет придерживаться фидуциарных стандартов и предпринимать меры по борьбе с коррупцией во всех своих проектах и программах.

vii. Содействие региональному сотрудничеству и интеграции. АБР улучшит взаимодействие в регионе и повысит конкурентоспособность РС4, расширит помощь в обеспечении региональных общественных благ и реализации совместных действий по смягчению таких трансграничных рисков, как изменение климата, загрязнение, энергетическая и водная безопасность, а также передаваемые контактным путем и инфекционные заболевания. АБР будет также укреплять сотрудничество в финансовом секторе и расширять субрегиональные инициативы, в том числе посредством содействия обмену знаниями и сотрудничеству, а также взаимодействия с новыми инициативами.

АБР расширит операции в частном секторе, объем которых к 2024 году достигнет трети от всех операций банка. АБР будет стремиться к оказанию воздействия в области развития как ключевой цели своих операций в частном секторе, что также обеспечит их прибыльность и коммерческую устойчивость. АБР будет расширять и диверсифицировать проекты в частном секторе на новых и пограничных рынках, таких как уязвимые и затронутые конфликтами страны и малые островные развивающиеся государства. АБР будет использовать фонды прямых инвестиций для расширения охвата и масштаба поддержки государственно-частных партнерств. АБР также увеличит в своих представительствах число сотрудников, занятых в проектах с частным сектором.

АБР будет стимулировать и привлекать финансовые ресурсы для развития и укреплять сотрудничество с многосторонними, двусторонними и частными партнерами. Банк будет изыскивать финансирование из коммерческих и льготных источников. АБР нацелен на существенное увеличение долгосрочного софинансирования к 2030 году, с тем, чтобы на каждый доллар финансирования проектов в частном секторе приходилось 2,5 доллара долгосрочного софинансирования. Для стимулирования инвестиций Банк будет взаимодействовать посредством государственно-частных партнерств, улучшать условия ведения бизнеса в РСЧ и более активно использовать внутренние ресурсы в этих странах.

АБР усилит деятельность в передаче знаний и будет тесно сотрудничать с РСЧ в целях выявления их потребностей и создания наиболее актуальных продуктов и услуг в области знаний. Это будет стимулировать персонал Банка к внедрению передовых разработок и финансирования и наращивания институционального потенциала в рамках всего операционного цикла. АБР будет активно участвовать в исследованиях, предоставлять высококвалифицированную консультативную помощь в области политики для РСЧ, укреплять их институциональный потенциал в решении проблем в области развития и реализации проектов, и расширять партнерство по передаче знаний. Банк будет также способствовать генерированию и обмену знаниями в рамках организации и в масштабах всего региона.

АБР будет стремиться стать более влиятельной, эффективной и динамичной организацией. Будет создана прочная ресурсная база для поддержки будущих операций АБР. АБР будет укреплять свои кадровые ресурсы и расширять присутствие в странах с помощью усиления в них своих представительств. АБР нацелен на кардинальную модернизацию бизнес-процессов (включая проведение своевременных и экономически 
эффективных закупок и более активное использование страновых закупочных систем) и ускорение цифровых преобразований. Банк будет также наращивать сотрудничество с организациями гражданского общества в проектировании, осуществлении и мониторинге проектов.

Для практической реализации стратегии АБР разработает операционные планы по семи приоритетным направлениям, для того чтобы обозначить основной стратегический курс, конкретные сферы деятельности, подходы и общие квалификационные требования. Страновые приоритеты будут в дальнейшем сформулирова- ны в стратегиях партнерства с конкретными странами. Рабочая программа и процессы бюджетирования будут доработаны и использованы для согласования годового плана работы и ресурсной базы с операционными приоритетами. Для мониторинга и оценки хода реализации стратегии будет разработана и обновлена новая матрица организационных результатов. АБР продолжит подготовку годовых отчетов по институциональным показателям с использованием матрицы результатов.

Для эффективной реализации Стратегии 2030 АБР внедрит подход "Один АБР", объединяющий знания и опыт всей организации. 


\section{І. ВВЕДЕНИЕ $७$}

1. За последние 50 лет Азиатско-Тихоокеанский регион добился большого прогресса в сокращении бедности и ускорении экономического роста и намерен достичь еще более впечатляющих результатов.' Азиатский банк развития (АБР) является ключевым партнером в существенном преобразовании региона и продолжит оказание помощи региону на следующем этапе его развития.

2. В новой долгосрочной стратегии до 2030 года Стратегии 2030 - обозначен курс деятельности АБР в ответ на меняющиеся потребности региона. Стратегия разработана по итогам различных оценок деятельности АБР, включая среднесрочный обзор Стратегии 2020, обзоры эффективности развития (ОЭР) и исследования, проведенные департаментом независимой оценки (ДНО).

3. Среднесрочный обзор Стратегии 2020. В среднесрочном обзоре, проведенном в 2014 году, проанализированы уроки, полученные в ходе реализации Стратегии 2020, и предложена 10-шаговая программа для усиления и перераспределения будущих стратегических направлений деятельности АБР, а также повышение его готовности и реагирования на изменения. ${ }^{2}$ Программа нацелена на сокращение бедности, инклюзивный экономический рост, охрану окружающей среды, противодействие изменению климата, региональное сотрудничество и интеграцию (РСИ), развитие инфраструктуры, оказание помощи странам со средним уровнем доходов, развитие частного сектора и осуществление совместных операций, а также внедрение интеллектуальных решений. В ней также описаны меры повышения потенциала АБР, эффективности и результативности в таких областях, как финансовые ресурсы и партнерства, бизнес-процессы, квалификация персонала, поощрения и организационные меры.
4. Оценка деятельности АБР. Итоги среднесрочного обзора подкрепляются результатами ежегодной оценки деятельности АБР в сопоставлении с организационной матрицей результатов в ОЭР и результатами, представленными в ДНО. В данных документах отмечается, что АБР осуществляет деятельность в соответствии с приоритетами Стратегии 2020 и добился позитивных результатов в таких областях, как развитие инфраструктуры, противодействие изменению климата и гендерные вопросы. Однако, эти выводы указывают также и на то, что АБР следует несколько перераспределить свои операции и усилить фокус на социальных секторах в целях расширения поддержки в снижении бедности и инклюзивного экономического роста. Для удовлетворения растущих региональных потребностей предлагается также сделать больший акцент на операциях в частном секторе, включая привлечение большего объема ресурсов. ДНО рекомендует АБР стремиться к более качественному росту (вместо количественного) посредством трех взаимодополняющих программ: социальной и географической интеграции, экологической устойчивости и РСИ. Кроме того, ДНО рекомендует АБР объединить свои экспертные знания по секторам и направлениям для решения более комплексных задач в области развития в рамках Стратегии 2030.

5. Замечания и предложения по итогам консультаций с заинтересованными сторонами. В Стратегии 2030 отражены мнения широкого круга заинтересованных сторон, включая лиц, разрабатывающих политику в развивающихся и развитых странах, ученых и представителей организаций гражданского общества (ОГО), а также членов Совета директоров и сотрудников АБР. В дополнение к страновым консультациям, проведенным по всему региону, были организованы четыре круглых стола с известными экспертами в области развития в Лондоне, Маниле, Токио и Вашингтоне. Заинтересованные стороны отмечают, что АБР продолжает играть важную роль в Азиатско-Тихоокеанском ре-

\footnotetext{
Азиатско-Тихоокеанский регион включает 48 стран Азии и Тихого Океана, которые являются членами Азиатского банка развития (АБР). Эти экономики разделены в целом на группу развивающихся стран-членов и развитые страны-члены. Термин "развитые страны-члены" относится к Австралии, Японии и Новой Зеландии. Оставшиеся 45 развивающихся стран-членов совместно именуются "развивающаяся Азия."

АБР. 2014 г. Среднесрочный обзор Стратегии 2020: Решение задач меняющегося Азиатско-Тихоокеанского региона. Манила.
} 


\section{В новой долгосрочной стратегии до 2030 года - Стратегии 2030 - обозначен курс деятельности АБР в ответ на меняющиеся потребности региона.}

гионе, даже, несмотря на то, что большинство из его развивающихся стран-членов (РСЧ) достигли статуса стран со средним уровнем доходов. Многие из этих стран по-прежнему сталкиваются с проблемами, вызванными укоренившейся нищетой и уязвимостью, глобальной экономической нестабильностью, неравенством, изменением климата и ухудшением состояния окружающей среды, урбанизацией и старением населения.
Для решения этих проблем АБР следует опираться на свои сильные стороны в финансировании инфраструктуры и РСИ; приумножать потенциал в социальных секторах и увеличивать операции в частном секторе, в том числе в рамках государственно-частных партнерств. Кроме того, АБР должен расширять услуги в области передачи знаний, содействовать обмену знаниями между странами и повышать эффективность бизнес-процессов. ${ }^{3}$

В Стратегии 2030 отражены замечания и предложения широкого круга заинтересованных сторон, включая лиц, разрабатывающих политику в развивающихся и развитых странах, ученых и представителей гражданского общества, а также членов Совета директоров и сотрудников.

Итоги данных оценок и резюме консультаций с заинтересованными стороны приведены в приложении. 


\section{II. МЕНЯЮЩИЙСЯ ЛАНДШАФТ И ВЫЗОВЫ 7}

6. Смещение экономического центра тяжести в сторону Азиатско-Тихоокеанского региона. Доля Азиатско-Тихоокеанского региона, как самого быстрорастущего региона в последние десятилетия, в мировом валовом внутреннем продукте увеличилась с 25\% в 2000 году до 33\% в 2016 году (График 1). Ожидается, что к 20504 году в регионе будет осуществляться более половины мирового производства. Китайская Народная Республика (КНР) и Индия входят в настоящее время в число крупнейших экономик мира. Страны Ассоциации государств Юго-Восточной Азии (АСЕАН), 5 с общим населением около 640 млн человек, стали значимыми развивающимися странами, ориентированными на рыночную экономику. Уверенный рост привел к резкому сокращению бедности по уровню доходов и улучшению качества жизни. В развивающихся странах крайняя нищета, измеренная на основе паритета покупательной способности, по предельному показателю в размере \$1.90/в день на 2011 год, существенно уменьшилась: с 53\% в 1990 году до 9\% от общего населения в 2013 году. ${ }^{6}$ Тем не менее, несмотря на то, что согласно прогнозам, такие позитивные тенденции продолжатся, в регионе сохраняется бедность. Кроме того, ожидаются стремительные и все более сложные перемены, вызванные глобальными событиями и новыми региональными вызовами.

7. Сохраняющиеся бедность и уязвимость. Сокращение бедности в Азиатско-Тихоокеанском регионе, даже в странах с относительно высоким уровнем доходов на душу населения, по-прежнему остается нерешенной задачей. В 2013 году, несмотря на значительный прогресс, 326 млн человек в регионе проживало в крайней

\footnotetext{
АБР. 2011 г. Азия 2050: Реализация азиатского века. Сингапур.

10 государств-членов АСЕАН - Бруней-Даруссалам, Камбоджа, Индонезия, Лаосская Народно-Демократическая Республика (ЛНДР), Малайзия, Мьянма, Филиппины, Сингапур, Таиланд и Вьетнам.

Всемирный банк. PovcalNet. http://iresearch.worldbank.org/PovcalNet/ home.aspx (по состоянию на 11 октября 2017 года). Показатели региональной бедности в 34 развивающихся странах Азии, в которых такие данные имеются: Армения, Азербайджан, Бангладеш, Бутан, Федеративные Штаты Микронезии, Фиджи, Грузия, Индия, Индонезия, Казахстан, Кирибати, Кыргызская Республика, Лаосская НародноДемократическая Республика, Малайзия, Мальдивские Острова, Монголия, Мьянма, Непал, Пакистан, Папуа-Новая Гвинея, Филиппины, КНР, Самоа, Соломоновы Острова, Шри-Ланка, Таджикистан, Таиланд, Тимор-Лешти.
}

График 1: Увеличение доли Азиатско-Тихоокеанского региона в мировом валовом внутреннем продукте, 2000 и 2016 гг.
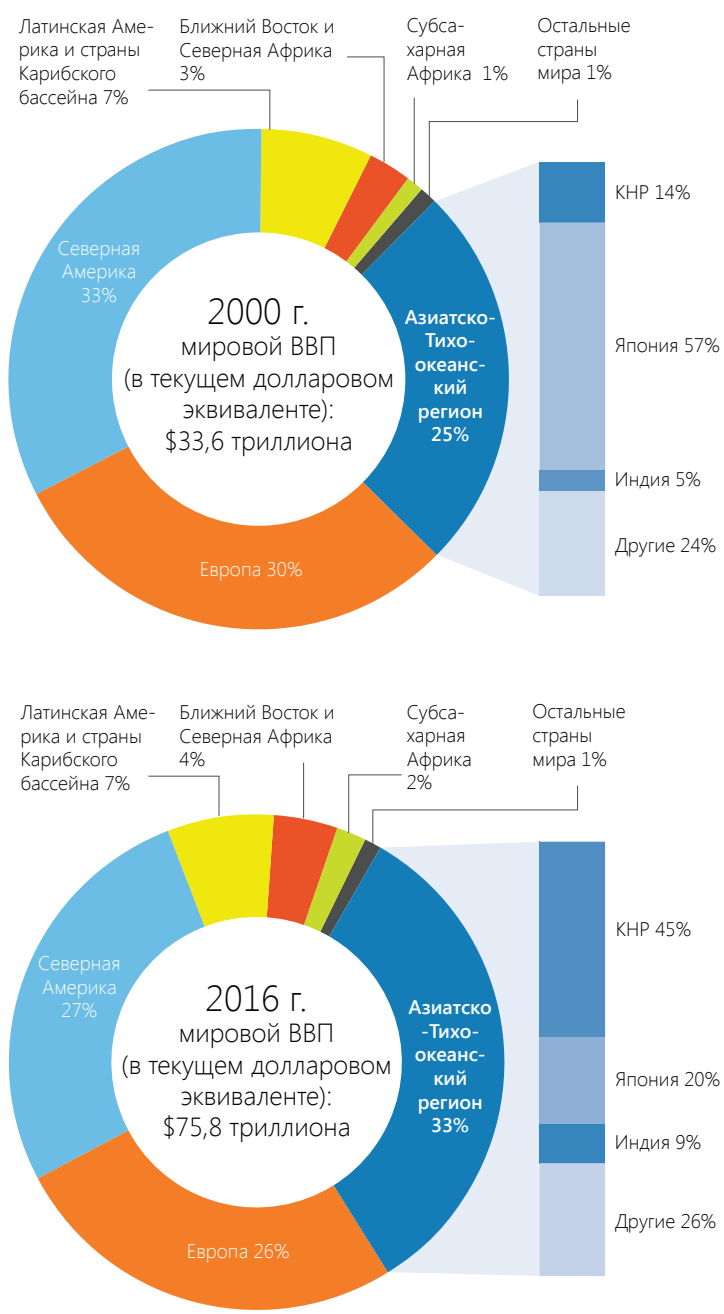

АБР = Азиатский банк развития, ВВП = валовой внутренний продукт, КНР = Китайская Народная Республика.

Примечание: В состав Азиатско-Тихоокеанского региона входят развивающиеся и развитые страны-члены АБР, за исключением островов Кука и Тайбэя в Китае, для которых данные отсутствуют. Показатели ВВП в долларах США пересчитываются на основе внутренних валют, используя официальные обменные курсы одного года

Источник: Всемирный банк. Показатели мирового развития. http://databank.worldbank.org/data/reports.aspx? source=worlddevelopment-indicators (по состоянию на 5 марта 2018 года). 


\section{2,246 млн показатель бедности $81 \%$}

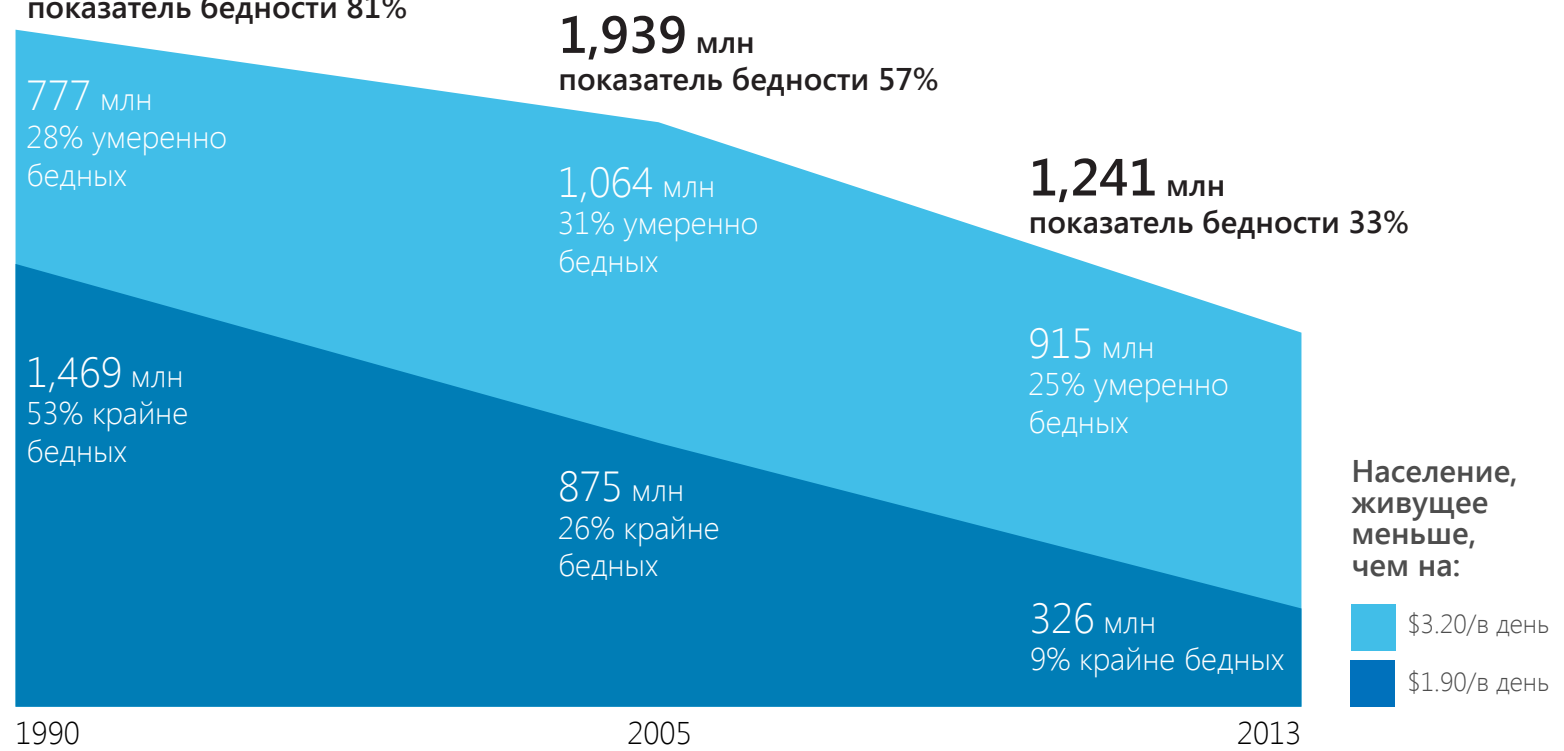

АБР = Азиатский банк развития

Примечания: Последним базовым годом, в котором была проведена оценка, является 2013 год. Прожиточный минимум выражен в паритете покупательной способности 2011 года. Некоторые цифры могут не совпадать с суммой показателей в связи с их округлением. Источник: Всемирный банк. PovcalNet. http://iresearch.worldbank.org/PovcalNet/home.аspх (по состоянию на 11 октября 2017 года).

бедности (или ниже показателя черты бедности \$1.90 в день) (График 2). Кроме того, 915 млн человек живут на более, чем \$1.90/в день, но меньше \$3.20/в день. Эти люди находятся под постоянным риском вновь оказаться в крайней нищете во время экономических спадов и других внешних потрясений. В 2016 году число людей, остро нуждающихся в пище, оставалось значительным: 64\% недоедающих людей в мире (около 520 млн) проживают в Азии. ${ }^{7}$

8. Растущее неравенство. В нескольких странах региона усилилось неравенство доходов и сохраняются социальные диспропорции. В период с 1990 по 2000 годы $^{8}$ около 80\% населения региона проживало в странах с растущим неравенством (измеряемое коэффициентом Джини). По-прежнему уровень нищеты в сельской местности выше, чем в городской; кроме того, наблюдаются существенные различия в посещаемости школ и успеваемости, доступе к электричеству, источникам водоснабжения и санитарно-гигиеническим сооружениям. ${ }^{9}$ Сохраняются, особенно в домашних хозяйствах, возглавляемых женщинами, гендерные различия в производительности, оплате труда и бедности, обусловленной отсутствием доходов. Растущее неравенство может подорвать сплоченность общества, ставит под угрозу

Продовольственная и сельскохозяйственная организация Объединенных Наций (ФАО), Международный фонд сельскохозяйственного развития, Детский фонд Организации Объединенных Наций (ЮНИСЕФ), Мировая продовольственная программа (МПП) и Всемирная организация здравоохранения (ВОЗ). 2017 г. Состояние продовольственной безопасности и питания в мире в 2017 году: укрепление устойчивости к миру и продовольственная безопасность. Рим: ФАО. Недоедание определяется как состояние, при котором привычного потребления пищи у человека недостаточно для обеспечения пищевой энергии, необходимой для поддержания нормальной, активной и здоровой жизни. Показатели для Азии основаны на страновой классификации ФАО.

Всемирный банк. Мировые показатели развития. http://databank.worldbank.org/data/reports.aspx?source=world-development-indicators (по cocтоянию на 15 февраля 2018 г). Из 22 стран с сопоставимыми данными, в 8-ми странах (Индия, Индонезия, Лаосская Народно-Демократическая Республика, Монголия, КНР, Шри-Ланка, Таджикистан и Вьетнам), на которые в 2015 году приходилось около 79\% населения развивающейся Азии, отмечалось повышение коэффициентов Джини в период между 1990-2000 годами.

9 АБР. 2017 г. Основные показатели Азиатско-Тихоокеанского региона, 2017 г., Манила. В 19 экономиках по показателям бедности, разделенных на городское и сельское население (согласно имеющимся данным национальных обследований доходов и расходов домашних хозяйств на период с 2010 по 2016 гг.), доля населения, живущего ниже черты бедности, официально установленной в конкретной стране, в сельской местности стабильно выше, чем в городах. 
социальную и политическую стабильность и препятствует экономическим перспективам региона.

9. Технологические достижения. Достижения в различных областях, включая мобильные и цифровые технологии, робототехнику, искусственный интеллект, «Интернет вещей» и трехмерную печать, кардинально изменят способы производства, распространения, доставки и потребления товаров и услуг. Благодаря этим технологиям, помимо прочего, могут возникнуть новые отрасли экономики и улучшится жизнь людей, усовершенствуются методы конструирования и управления инфраструктурой, системы здравоохранения, расширится доступ к финансовым услугам, повысится степень подотчетности правительства и участие гражданского общества. Однако есть опасения относительно охвата и степени воздействия технологий на общество, включая возможность перемещения рабочей силы (См. вставку). Для того чтобы быть готовыми к таким негативным возможным последствиям, правительства должны должным образом адаптировать свои системы образования, обучения и социальной защиты.

10. Изменение климата и риск стихийных бедствий. Изменение климата и стихийные бедствия ставят под угрозу долгосрочное устойчивое развитие региона.
В последние десятилетия в Азиатско-Тихоокеанском регионе наблюдается значительное повышение регулярности, интенсивности и воздействия таких экстремальных погодных явлений, как тропические циклоны, наводнения, засухи и периоды аномально жаркой погоды. Геофизические опасные явления, включая землетрясения и цунами также становятся причиной гибели большого числа людей и экономического урона. Среди 10 стран с наиболее высоким оценочным уровнем риска стихийных бедствий семь являются развивающимися странами-членами АБР. ${ }^{\circ}$ Особенно уязвим Тихоокеанский регион, поскольку прогнозируемое повышение уровня моря угрожает в долгосрочной перспективе жизнеспособности многих его островов."

\section{1. Усиление давления на окружающую среду. K чис-} лу основных экологических проблем, стоящих перед регионом, относятся загрязнение воздуха, недостаток и загрязнение воды, замусоривание моря, береговой линии и прибрежных зон, ненадлежащее управление водными ресурсами, вырубка лесов, деградация земель и потеря биоразнообразия. Усиление давления на окружающую среду подрывает устойчивость и усугубляет существующую уязвимость бедных слоев населения, которые несоразмерно зависят от экосистемных услуг в обеспечении средств к существованию и продоволь-

\section{АЗИЯ И ТЕХНОЛОГИЧЕСКОЕ РАЗВИТИЕ}

Технологические разработки открывают широкие возможности для взаимодействия людей, развития торговли и доступа к необходимым услугам. Новые технологии расширяют платформу для образования (с помощью онлайн курсов и виртуальных аудиторий) и здравоохранения (например, телемедицина). Цифровые рынки и онлайн услуги создают новые торговые механизмы для малых и средних предприятий, а такие технологии, как блокчейн, могут коренным образом изменить систему платежей и логистику и помочь расширить доступ к финансовым услугам. Новейшие технологические достижения повысили конкурентоспособность возобновляемых источников энергии по отношению к источникам природного топлива и открыли доступ к электричеству через локализованные возобновляемые электросети. Современные коммуникации теперь могут достигать отдаленных районов по относительно низкой цене.

Технологические изменения ускоряют экономический рост и улучшают условия жизни. Однако возникают также опасения относительно того, что многие рабочие места находятся под угрозой из-за усиления сложности робототехники и искусственного интеллекта. Наряду с созданием, благодаря внедрению технологий, рабочих мест, в том числе и в новых отраслях, может возникнуть необходимость в тех навыках, которые в настоящее время у большинства работников отсутствуют, что может стать причиной безработицы и/или низкооплачиваемых видов работ для менее квалифицированных кадров. Перед регионом стоит задача извлечения пользы из тех возможностей, которые открывают технологии, обеспечивая при этом готовность к рискам и смягчению последствий.

Источник: Азиатский банк развития. 2018 г. Прогноз развития Азии на 2018 г. Манила.

\footnotetext{
10 Бангладеш, Камбоджа, Филиппины, Соломоновы Острова, Тимор-Лешти, Тонга и Вануату. Л. Кирч и другие. 2017 г. Отчет по глобальным рискам: анализ и перспективы 2017 г. Берлин Bündnis Entwicklung Hilft.

АБР. 2013 г. Экономика изменения климата в Тихоокеанском регионе. Манила.
} 


\section{График 3: Выбросы углекислого газа по регионам}

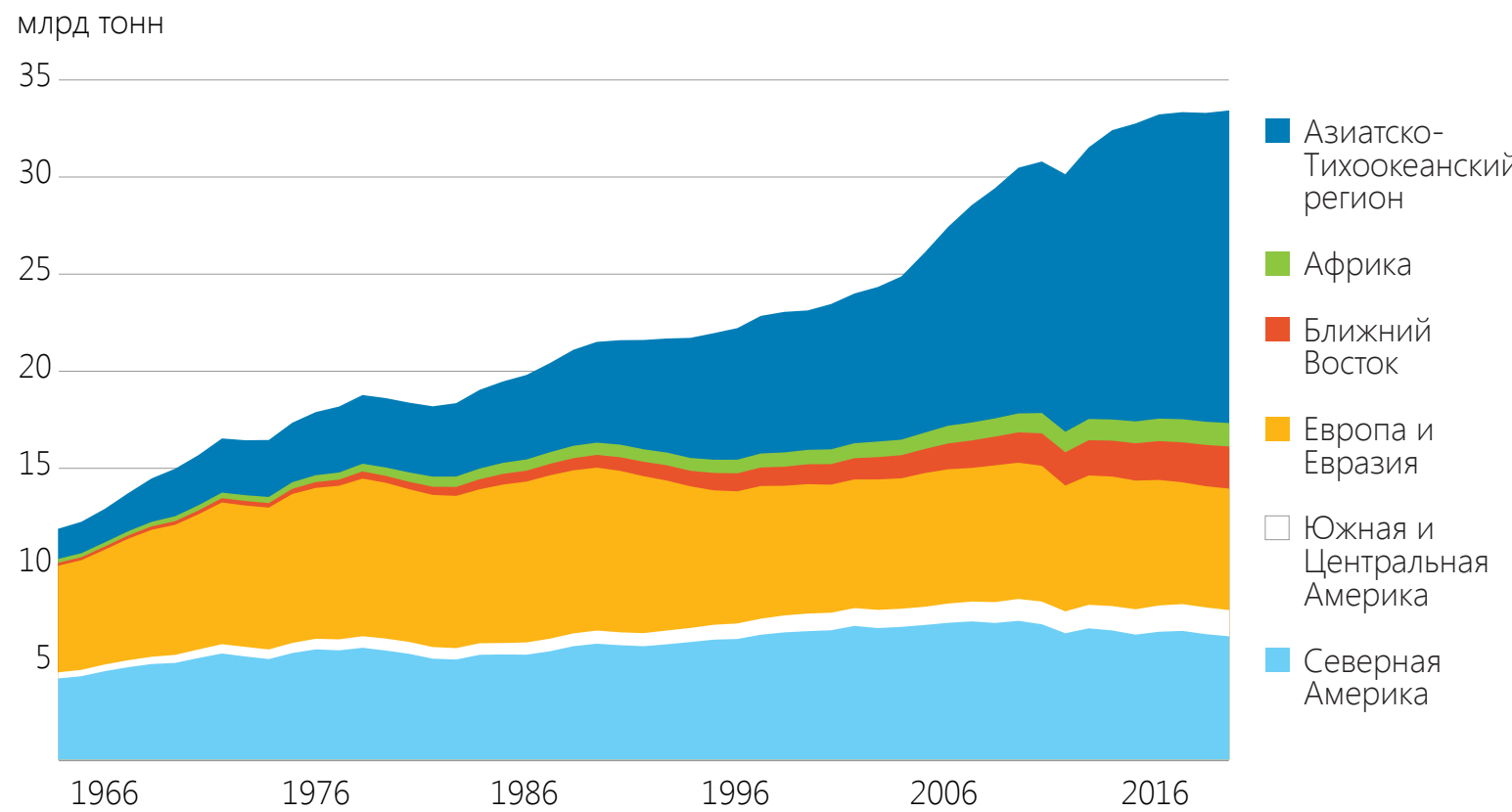

Примечание: Относится к выбросам углерода от потребления нефти, газа и угля от деятельности, связанной со сжиганием топлива. Источник: ВР. Статистический обзор мировой энергетики за 2017 год. Лондон.

ственной безопасности. Регион также страдает от нехватки воды из-за изменения климата, а также в связи с быстрым ростом населения и ускоренным экономическим развитием. Для региона принципиально важно применять комплексный подход к освоению водных и продовольственных ресурсов и обеспечению энергетической безопасности. Около 70\% водных ресурсов в Азии задействовано для выращивания продуктов питания, более того, вода используется для производства энергии. Еще одной важной задачей является сохранение и экономия ресурсов с помощью новых технологий и эффективной государственной политики.
12. Амбициозные цели развития. Международную повестку дня в области развития формируют Цели устойчивого развития (ЦУР), Парижское соглашение по изменению климата, Сендайская рамочная программа по снижению рисков стихийных бедствий и Программа действий, принятая в Аддис-Абебе (нацеленная на использование миллиардов для мобилизации триллионов). В Целях устойчивого развития все страны призываются к более активным усилиям по искоренению нищеты, защиты планеты и установлению всеобщего мира и процветания. ${ }^{2}$ В Парижском Соглашении изложен план удержания роста глобального потепления на уровне ниже $2^{\circ} \mathrm{C} .{ }^{3}$ Учитывая размеры населения региона, достижение основных ЦУР по искоренению нище- 


\section{Учитывая размеры населения региона, достижение основных ЦУР по искоренению нищеты, голода, отсутствия доступа к социальным услугам в решающей степени будет зависеть от успешных результатов в Азиатско-Тихоокеанском регионе. В регионе можно также определить направление глобальных усилий по сокращению выбросов парниковых газов (ПГ), поскольку в нем выбросы ПГ растут самыми быстрыми темпами. По данным 2016 года, на регион приходится 48\% глобальных выбросов углекислого газа в энергетическом секторе.}

ты, голода, отсутствия доступа к социальным услугам в решающей степени будет зависеть от результатов в Азиатско-Тихоокеанском регионе. ${ }^{14}$ В регионе также имеются возможности по формированию глобальных усилий для сокращения выбросов парниковых газов (ПГ), поскольку данный регион является самым быстрорастущим источником выбросов ПГ, на который, по данным 2016 года, приходится 48\% глобальных выбросов углекислого газа в энергетическом секторе. (График 3)..$^{15}$

4 Всемирный банк. PovcalNet. http://iresearch.worldbank.org/PovcalNet/ home.aspx (по состоянию на 11 октября 2017 г.). Экономическая и Социальная Комиссия для Азиатско-Тихоокеанского региона. Программа Организации Объединенных Наций по окружающей среде и др. 2016 г. Преобразования для устойчивого развития: содействие экологической устойчивости в Азиатско-Тихоокеанском регионе. http://www.unescap.org/sites/default/files/Full\%20report.pdf; и ФАО, Международный фонд сельскохозяйственного развития, ЮНИСЕФ, МПП и ВОЗ. 2017 г. Состояние продовольственной безопасности и питания в мире на 2017 год: укрепление устойчивости к миру и продовольственная безопасность. Рим: ФАО. По последним оценкам, в Азиатско-Тихоокеанском регионе проживает 43\% крайне бедного населения развивающихся стран (с использованием паритета покупательной способности 2011 г. в размере 1,90 долл. США в день, определение «развивающийся мир» относится ко всем странам с низким и средним уровнем доходов по базе данных PovcalNet, используя Страновую классификацию Всемирного банка), 64\% недоедающих людей в мире, 35\% мирового населения без доступа к электричеству, 42\% мирового населения без доступа к качественным источникам водоснабжения и 63\% мирового населения без доступа к элементарным санитарным условиям.

15 ВP PIc. Статистический обзор мировой энергетики за 2017 г. Лондон. Выбросы углерода относятся только к выбросам от потребления нефти, газа и угля для деятельности, связанной с сжиганием, и основаны на коэффициентах выбросов углекислого газа по умолчанию для сжигания, перечисленных в национальных кадастрах ПГ Межправительственной группы экспертов по изменению климата (МГЭИК, 2006 г.). Руководящие принципы МГЭИК для национальных кадастров парниковых газов. Япония). Данные не включают секвестрацию углерода, другие источники выбросов углерода или выбросы других парниковых газов. Показатели для Азии основаны на группировке стран БП.

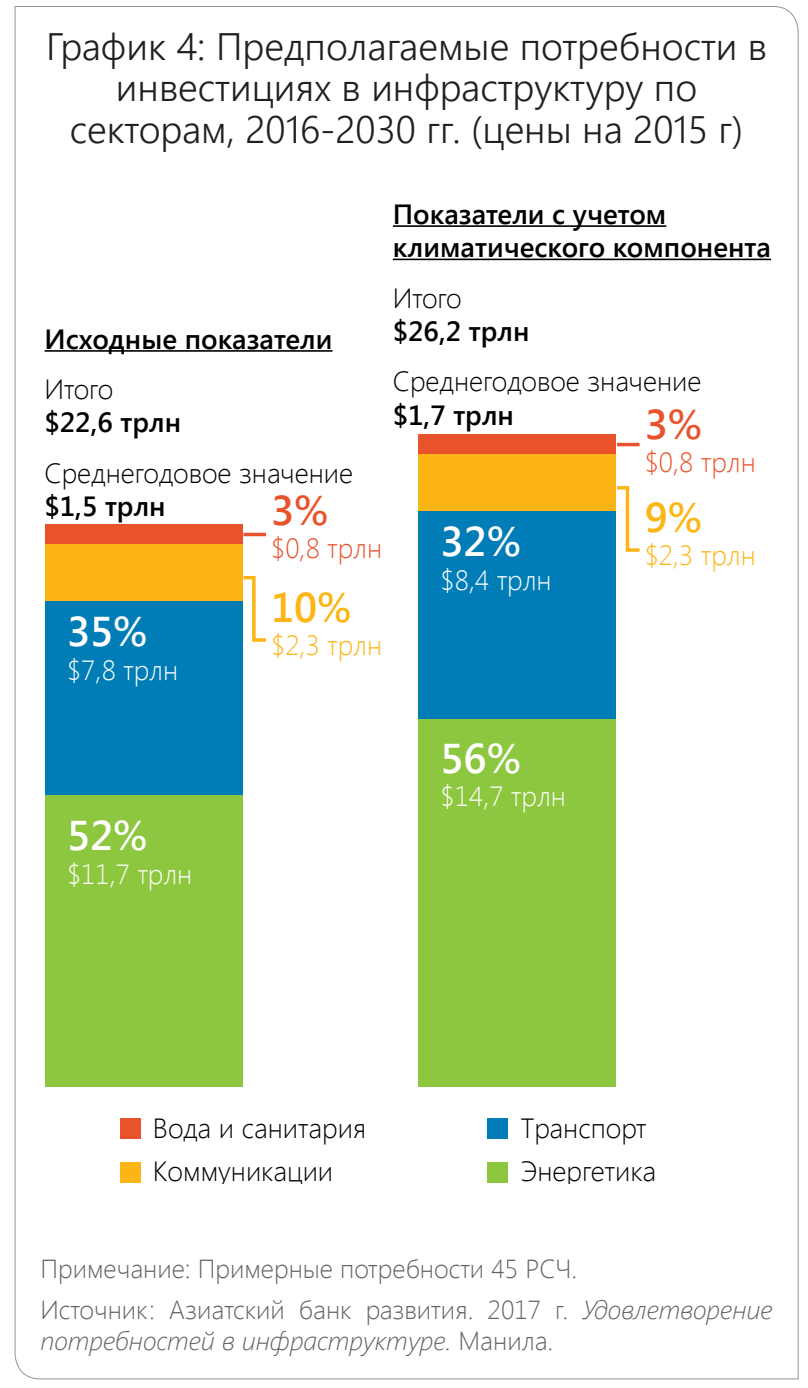


13. Появление новых партнеров в области развития. За последнее десятилетие значительно увеличилось число субъектов регионального и глобального развития, действующих в Азиатско-Тихоокеанском регионе, включая организации гражданского общества, нетрадиционных доноров, таких как благотворительные или филантропические организации, а также новых многосторонних банков развития, например, Азиатский банк инфраструктурных инвестиций и Новый банк развития. С ростом необходимости притока частного капитала следует стимулировать частный сектор к более активному участию в процессах развития. Крайне важно координировать и оптимизировать партнерские отношения на национальном, институциональном и государственно-частном уровнях.

14. Воздействие глобализации. Тесная интеграция с глобальными рынками способствовала росту торговли в регионе и притока в него внешнего капитала. Сформировались комплексные глобальные производственно-сбытовые цепочки, в результате которых возникли производственные сети в рамках национальных границ. Это стало одним из самых значимых факторов роста региона в условиях рыночных реформ и макроэкономической стабильности. В то же время, интеграция с глобальными сетями повысила уязвимость национальной экономики внешним потрясениям. Последствия рецессии и волатильности рынков капитала усугубляются и затрагивают другие области. Глобальный финансовый кризис 2007-2009 годов выявил риски крупных финансовых потоков в эпоху жестко взаимоувязанных финансовых рынков. Усиление неравенства во многих странах также обусловлено глобализацией и внедрением современных технологий.

15. Нехватка инфраструктуры. Регион по-прежнему нуждается в значительных ресурсах для устранения нехватки инфраструктуры, особенно в отстающих областях. Более 400 млн человек в Азии живут без электричества, ${ }^{16}$ около 300 млн не имеют доступа к питьевой воде, и 1,5 миллиарда не обеспечены элементарными санитарными условиями. ${ }^{17}$ Неотложной задачей являет- ся замена или модернизация инфраструктуры низкого качества. Во многих странах экономическому росту препятствуют перебои в электроснабжении, а слаборазвитые транспортные сети ограничивают перемещение людей и поток товаров и услуг. Важной задачей региона является восстановление и повышение эффективности управления и эксплуатации инфраструктурных активов. По самым последним данным АБР, в период с 2016 по 2030 годы в инфраструктурные проекты АзиатскоТихоокеанского региона, для того чтобы сохранить темпы роста, искоренить нищету и противодействовать последствиям изменения климата, потребуется \$26,2 трлн или \$1,7 трлн в год (График 4). Важнейшим источником финансирования должен стать частный сектор.

16. Быстрая урбанизация. Доля городского населения в регионе увеличилась приблизительно с 20\% в 1950-х годах до около 48\% в 2018 году. К 2030 году прогнозируется рост до 55\%, или примерно до 2,5 млрд городских жителей. ${ }^{18}$ Быстрая урбанизация сопряжена как с возможностями, так и с вызовами. Перед сельскими жителями, переехавшими в города, как правило, открываются новые экономические возможности, для них зачастую упрощается доступ к услугам здравоохранения и образования и в целом условия их жизни улучшаются. Однако, города в Азиатско-Тихоокеанском регионе быстро увеличиваются в размере и ими становится все сложнее управлять. Требуются меры противодействия ухудшению состояния окружающей среды и решение проблемы масштабной нехватки городской инфраструктуры. По данным 2014 года, в развивающейся Азии 431 млн человек проживало в трущобах, что составляет 58\% мирового населения, живущего в трущобах. ${ }^{19}$ Города, особенно те, которые расположены вдоль береговых линий, все в большей степени подвержены рискам стихийных бедствий.

17. Демографические изменения. Поскольку продолжительность жизни населения в ряде РСЧ увеличивается, а коэффициент рождаемости при этом снижается, в регионе наблюдается стремительное старение населения. По прогнозам Организации Объединенных Наций,

16 Экономическая и социальная комиссия для Азиатско-Тихоокеанского региона, АБР, и Программа развития ООН. 2017 г. Искоренение нищеты и содействие процветанию в изменяющемся Азиатско-Тихоокеанском регионе. Бангкок.

ЮНИСЕФ и ВОЗ. 2015 г. Прогресс в сфере санитарии и питьевой воды: обновленная информация за 2015 год и оценка достижения ЦРТ. Женева.

18 Департамент ООН по экономическим и социальным вопросам, отдел народонаселения. 2018 г. Перспективы мировой урбанизации: пересмотр на 2018 г. Нью-Йорк.

19 Всемирный банк. Показатели мирового развития. http://databank.worldbank.org/data/reports.aspx?source=world-development-indicators (по cocтоянию на 19 февраля 2018 г.). 
количество пожилого населения (люди в возрасте 65 лет и старше) в Азиатско-Тихоокеанском регионе увеличится примерно с 334 млн в 2016 году до около 870 млн к 2050 году. В течение этого периода доля этой категории в общей численности населения будет увеличиваться с 8,1\% до 18,1\%. ${ }^{\circ}$ С ростом доли пожилых людей по отношению к работающему населению правительства сталкиваются с финансовыми проблемами, такими как снижение налоговых поступлений и увеличение расходов на здравоохранение. Пожилые люди в развивающихся странах-членах АБР, особенно женщины, часто не имеют достаточной пенсии или медицинского страхования. В ряде РСЧ, напротив, отмечается рост молодого населения. В Азиатско-Тихоокеанском регионе проживает 2 млрд человек в возрасте до 30 лет, что составляет 54\% мирового молодого населения. ${ }^{21}$ Благоприятная демографическая обстановка или демографические дивиденды часто сопряжены с сильным экономическим развитием и социальным прогрессом, но это зависит от способности РСЧ предложить качественные рабочие места и максимально повысить производительность труда. ${ }^{22}$

\section{8. Организация управления и институциональный} потенциал. Для должного противодействия вызовам и использования возможностей, возникающих в условиях меняющейся обстановки в регионе, необходима эффективно организованная система управления. Тем не менее, многие страны в регионе по-прежнему сталкиваются с проблемами управления, включая слабый уровень общественных услуг и государственных учреждений и коррупцию. Для сохранения динамики развития и обеспечения справедливого и широкого распределения благ, необходимы реформы управления по борьбе с коррупцией и укреплению профессиональных гражданских служб, законодательному регулированию и соблюдению верховенства права.

20 Департамент ООН по экономическим и социальным вопросам, отдел народонаселения. 2017 г. Перспективы мирового населения: пересмотр на 2017 г. Нью-Йорк.

21 Департамент ООН по экономическим и социальным вопросам, отдел народонаселения. 2017 г. Перспективы мирового населения: пересмотр на 2017 г. Нью-Йорк.

22 Под редакцией Д. Парк, С-Х. Лии и Э. Мэйсон. 2011 г. Старение населения, экономический рост и система страхования по старости в Азии. Манила: АБР/ Челтенхем, Великобритания; и Нортгемптон, Массачусетс, США: издательство «Edward Elgar Publishing». 


\section{III. ВИДЕНИЕ И ВКЛАД АБР

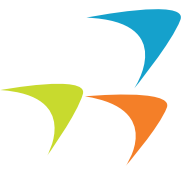

19. Видение АБР Азиатско-Тихоокеанского региона. По мере преобразования региона и изменения его потребностей и стоящих перед ним вызовов, АБР

Учитывая, что задача

искоренения бедности попрежнему на повестке дня

региона, Стратегия 2030

призвана усилить вклад АБР

в решение этой проблемы

и расширить видение

достижения процветающего,

инклюзивного, жизнестойкого

и устойчивого Азиатско-

Тихоокеанского региона.

АБР продолжит уделять

первостепенное внимание

беднейшим и наиболее

уязвимым странам региона. также вносит изменения в свою стратегию работы в регионе. Учитывая, что задача искоренения нищеты по-прежнему на повестке дня региона, Стратегия 2030 призвана усилить вклад АБР в решение этой проблемы и расширить видение достижения процветающего, инклюзивного, жизнестойкого и устойчивого АзиатскоТихоокеанского региона. Реализация стратегии будет способствовать развитию региона через поддержку качественного экономического роста и создание рабочих мест. АБР будет продвигать инклюзивный подход для обеспечения широкого доступа к экономическим достижениям, оказывать помощь в укреплении жизнестойкости и устойчивости стран, особенно в отношении уязвимых слоев населения, и наращивать РСИ (График 5). АБР будет по-прежнему уделять первоочередное внимание беднейшим и наиболее уязвимым странам.

20. Выполнение глобальных обязательств. Цели АБР в Азиатско-Тихоокеанском регионе согласованы с основными глобальными обязательствами, которые приняли на себя как РСЧ, так и АБР - ЦУР и соответствующие программы финансирования в области развития, Парижское соглашение по изменению климата и Сендайская Рамочная программа по снижению рисков стихийных бедствий. Структура будущих операций АБР будет разработана таким образом, чтобы помочь в достижении этих целей и задач. ${ }^{23}$ АБР будет также играть важную роль в поддержке выполнения программы G20 (Группы 20) по развитию инфраструктуры как источника глобального роста.

23 Видение АБР процветающего, инклюзивного, жизнестойкого и устойчивого Азиатско-Тихоокеанского региона согласуется с ЦуР и Программой развития до 2030 года. Основными целями АБР являются ликвидация бедности (ЦУР 1); обеспечение гендерного равенства (ЦУР 5); обеспечение доступа к недорогостоящим, надежным, устойчивым и современным источникам энергии (ЦУР 7); достойные условия труда и экономический рост (ЦУР 8); создание прочной инфраструктуры, содействие индустриализации и внедрению инноваций (ЦУР 9); снижение уровня неравенства (ЦУР 10); и принятие мер по борьбе с изменениями климата (ЦУР 13). Операции АБР будут также способствовать ликвидации голода (ЦУР 2), обеспечению здорового образа жизни и содействию благополучию для всех в любом возрасте (ЦУР 3), обеспечению качественного образования (ЦуР 4), наличию и рациональному использованию водных ресурсов и санитарно-гигиенических сооружений (ЦУР 6), устойчивых городов и сообществ (ЦУР 11), обеспечению рациональных моделей потребления и производства (ЦУР 12), установлению мира и справедливости, эффективных учреждений на всех уровнях (ЦУР 16). Помощь АБР в сохранении и восстановлении природного капитала (пункт 52), океанов, морей и морских ресурсов в целях устойчивого развития (ЦУР 14) и жизни на суше (ЦУР 15). АБР будет также играть важную роль в усилении механизмов партнерств для достижения ЦУР (ЦУР 17). 
21. Укрепление устойчивого развития с помощью проектов в социальных сферах и инфраструктуре. Расширяя деятельность в таких социальных областях, как образование, здравоохранение и социальная защита, АБР по-прежнему ставит основным приоритетом инфраструктурные проекты, поскольку именно инфраструктура играет жизненно важную роль в экономическом росте и социальном развитии. Инвестиции в устойчивую инфраструктуру занимают центральное место в выполнении глобальных обязательств по борьбе с изменением климата и повышению эффективности управления рисками стихийных бедствий. ${ }^{24}$ Развитие инфраструктуры также важно для удовлетворения растущих потребностей в высококачественном образо- вании, здравоохранении и других социальных услугах; противодействия таким вызовам, как старение населения; развитии адаптации новых технологий. АБР будет выделять инвестиции на экологически безопасную, устойчивую, надежную и комплексную инфраструктуру. В рамках инфраструктурных проектов АБР будет стремиться к улучшению доступа для бедных слоев населения, женщин и уязвимых групп (включая пожилых людей и лиц с ограниченными возможностями) к базовым услугам по энергообеспечению, транспорту, чистой воде и санитарно-гигиеническим сооружениям. АБР будет способствовать укреплению связей внутри стран и между ними для ускорения экономического роста и дальнейшего снижения бедности.

\section{График 5: Видение, вклад и руководящие принципы АБР}

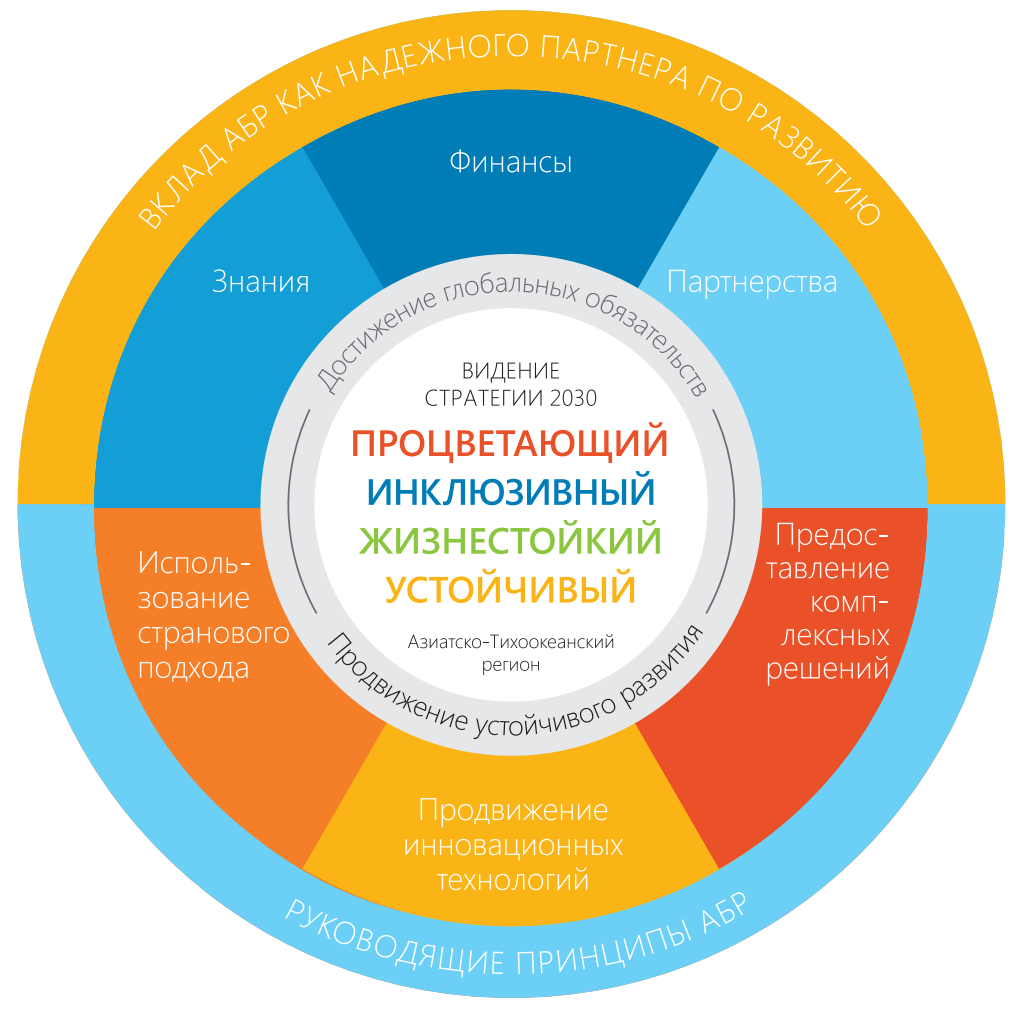

АБР - Азиатский банк развития.

Источник: Азиатский банк развития.

24 Устойчивая инфраструктура спроектирована, построена и эксплуатируется таким образом, чтобы обеспечить ее долговечность, общедоступность, а также экономическую и экологическую эффективность. АБР. 2018 г. Годовой отчет 2017 г. Манила. 
22. Вклад АБР. АБР останется надежным партнером в области развития, осуществляя свою деятельность на высоком качественном уровне. Имея сильную позицию и многолетний опыт взаимодействия с правительствами и различными организациями на местах, АБР открывает уникальные перспективы для региона. Для достижения максимального эффекта помощь АБР конкретной стране будет включать в себя финансирование, передачу знаний и создание партнерств. Как надежная финансирующая организация и катализатор финансирования, АБР будет предоставлять собственное финансирование, одновременно мобилизуя и привлекая средства из других источников. В роли поставщика знаний АБР будет уделять большое внимание их практической ценности применительно к местной специфике, проводить анализ извлеченных уроков и распространять передовые практики (в том числе пере- дачу технологий, экологические и социальные гарантии и фидуциарные стандарты) внутри региона и за его пределами. В роли координатора партнерских проектов, АБР будет оказывать содействие в установлении диалога и сотрудничества между различными партнерами и заинтересованными сторонами, в том числе с международными финансовыми организациями, двусторонними партнерами в области развития, благотворительными и филантропическими организациями, ОГО и частным сектором. В соответствии с задачами G20, направленными на укрепление глобального финансового управления, сотрудничество с Международным валютным фондом и другими многосторонними банками развития будет направлено на достижение максимального воздействия помощи международных финансовых учреждений в целом. АБР также намерен расширить свою деятельность в качестве разработчика проектов. 


\section{IV. РУКОВОДЯЩИЕ ПРИНЦИПЫ ОСУЩЕСТВЛЕНИЯ 7 ОПЕРАЦИЙ АБР}

23. Применение странового подхода. Амбициозная глобальная программа в области развития должна быть адаптирована к конкретным местным особенностям. РСЧ, в том числе страны с аналогичными размерами дохода на душу населения, существенно различаются в потребностях, институциональных преимуществах и наличии ресурсов. АБР будет приспосабливать свой подход с учетом различий в потребностях своей разнообразной клиентской базы. В рамках Стратегии 2030 АБР будет усиливать политический диалог и аналитическую работу, в том числе в достижении целевых страновых показателей по ЦУР и Парижскому соглашению. Страновая стратегия партнерства остается основной платформой для определения первоочередных задач РСЧ как двигателя своего развития и АБР как партнера, предоставляющего индивидуальные решения для удовлетворения потребностей и противодействия вызовам в области развития. На уровне стран АБР будет применять избирательный подход, для того чтобы исключить, допуская разумную гибкость, распыление ресурсов. Участие АБР в конкретных программах или секторах на уровне стран будет основываться на его конкурентных преимуществах перед другими партнерами в области развития, специфическими потребностями страны и потенциалом увеличения добавленной стоимости и общего объема ресурсов АБР. Опираясь на успешный

\section{РСЧ, в том числе страны с}

аналогичными размерами дохода

на душу населения, существенно

различаются в потребностях,

институциональных преимуществах

и наличии ресурсов. АБР будет

адаптировать подходы с учетом

различий в потребностях своей

разнообразной клиентской базы. опыт в реализации совместных проектов, АБР продолжит укреплять взаимодействие и партнерства с другими международными финансовыми организациями, двусторонними партнерами, ОГО и коммерческими структурами.

24. Продвижение инновационных технологий. АБР будет более активно изыскивать способы внедрения передовых технологий в операции Банка и оказывать поддержку РСЧ в наращивании потенциала в этом направлении посредством разработки политики и совершенствования нормативно-правовых условий для цифровой экономики, расширения возможностей подключения к Интернету и инвестирования в компьютерное оборудование и программное обеспечение. В инфраструктурных проектах АБР будет продвигать передовые технологии, которые позволят сократить затраты за срок службы, повысить долговечность и эффективность, улучшить качество услуг и свести к минимуму негативное экологическое и социальное воздействие. АБР будет широко внедрять передовые технологии через пилотные испытания, совершенствование проектных разработок, повышение качества проведения закупок и привлечение профильных экспертов.

25. Разработка комплексных решений. Используя экспертный опыт и знания в различных секторах и тематических направлениях, АБР предложит своим клиентам комплексные решения. Они будут реализованы в рамках эффективного сочетания операций в государственном и частном секторах, которые наилучшим образом отвечают специфическим нуждам на местах. АБР намерен усилить подход «Один АБР» в организации работы своих сотрудников в проектах с государственным и частным секторами, для того чтобы вести систематическую оценку потенциала частного сектора - как в плане оказания услуг, так и финансирования. Страновая стратегия партнерства будет служить в качестве основной платформы для внедрения таких комплексных решений с помощью более активного вовлечения партнеров в стране и усиление постоянных представительств АБР. 


\section{V. ДИФФЕРЕНЦИРОВАННЫЕ

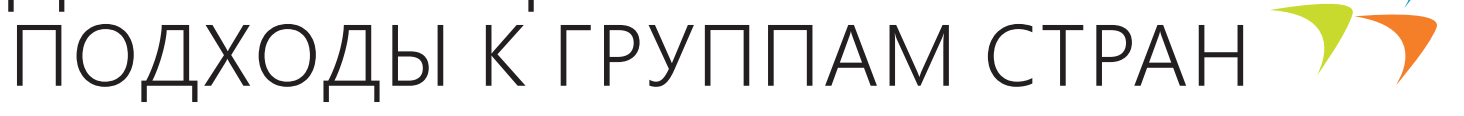

26. Нестабильные и затронутые конфликтами страны. Нестабильные и затронутые конфликтами страны (FCAS) находятся в состоянии крайней уязвимости и крайне нуждаются в укреплении институционального потенциала. ${ }^{25}$ В странах категории FCAS AБР сконцентрирует помощь в области институционального развития и проведении реформ системы управления, создании базовой инфраструктуры и социальных услуг, а также оказании адресной социальной помощи. АБР поддержит меры укрепления устойчивости, устранения коренных причин конфликтов, восстановления и реконструкции инфраструктуры. Для того чтобы в ССП и операциях АБР достаточное внимание уделялось проблемам неустойчивых и затронутых конфликтами стран, Банк также внесет вклад в повышении квалификации персонала, приспособление бизнес-процессов к реальной ситуации на местах и усилит сотрудничество с другими партнерами в области развития и ОГО. АБР увеличит объем ресурсов для покрытия дополнительных расходов на подготовку и контроль за обеспечением безопасности и решением других связанных с этим задач, для того чтобы в странах, переживших конфликты и нестабильность, вновь не обострилась ситуация.

27. Малые островные развивающиеся страны. В Уставе АБР малым или менее развитым странам-членам в регионе уделяется особое внимание. ${ }^{26}$ Малые островные развивающиеся государства (SIDS) особенно подвержены потрясениям, связанным с изменением климата или стихийными бедствиями. Их богатое биоразнообразие и прибрежные зоны крайне предрасположены к экологической деградации. Экономика в этих странах зачастую ограничена узкими внутренними рынками, высокой стоимостью ведения бизнеса и сложностями выхода на региональные и междуна- родные рынки. Для SIDS, так же, как и для стран FCAS, характерны серьезные ограничения в институциональном потенциале. По этой причине, многие развивающиеся страны-члены, классифицированные АБР как страны FCAS, представляют собой малые островные государства, хотя для них риск возникновения конфликтов не является доминирующим. ${ }^{27}$ Такие страны отличает крайняя уязвимость к экономическим потрясениям, которая со временем только усиливается ввиду узкой экономической базы, ограниченных ресурсов и сильной зависимости от внешних поставок многих жизненно необходимых товаров и услуг. В Стратегии 2030 предусматривается усиление фокуса АБР на данной категории стран (в том числе тех SIDS, которые не входят в группу FCAS). ${ }^{28}$ Помощь АБР будет сосредоточена на таких областях, как адаптация к последствиям изменения климата, экологическая устойчивость и управление рисками стихийных бедствий. АБР продолжит расширять участие в таких областях, как информационно-коммуникационные технологии, (ИКТ), морской и воздушный транспорт. АБР акцентирует внимание на укреплении институционального потенциала с тем, чтобы оказать содействие данной группе стран в управлении финансовыми и экономическими рисками. Это поможет SIDS улучшить бизнес среду, провести реформу государственных предприятий (ГП), повысить уровень государственно-частных партнерств (ГЧП) и, таким образом, сократить расходы на ведение бизнеса, улучшить качество государственных услуг и стимулировать рост, обусловленный частным сектором. АБР продолжит адаптировать свои бизнес-процессы применительно к потребностям малых островных стран для устранения ограничений и наращивания их технического потенциала и поддержки реализации, подобно тому, каким образом оказывается в настоящее время помощь в рамках

25 АБР классифицирует страну как FCAS, используя гармонизированный общий подход Африканского банка развития, АБР и Всемирного Банка.. В операционном плане АБР по FCAS предусмотрено, что по согласованию со страной можно включать другие страны, находящиеся в подобных ситуациях нестабильности и конфликта на субнациональном уровне. По состоянию на июнь 2018 года в перечень стран FCAS новые страны не были включены. АБР. 2013 г. Операционный план повышения эффективности АБР в затронутых конфликтами и нестабильных странах. Манила.

26 АБР. 1966 г. Соглашение о создании АБР. Манила.

27 OOH классифицирует SIDS. По состоянию на май 2018 года, из девяти РСЧ в АБР, выделенных в категорию FCAS, семь входили в группу SIDS. AБР будет периодически пересматривать и уточнять критерии определения страны как FCAS и SIDS, по согласованию с другими партнерами в области развития.

28 SIDS, которые на настоящий момент не входят в категорию FCAS, включают острова Кука, Фиджи, Мальдивы, Палау, Самоа, Тимор-Лешти, Тонга и Вануату. 
В соответствии со своим видением обеспечения всеобщего охвата АБР будет уделять приоритетное внимание поддержке
отстающих районов и очагов бедности в РСЧ, в том числе в
странах с доходами выше среднего.

Плана действий по улучшению Тихоокеанского проекта, и усиливать далее свое присутствие на местах. ${ }^{29}$

\section{8. Страны с низким уровнем дохода и доходом} ниже среднего уровня. Страны с низким уровнем дохода и доходом ниже среднего уровня сталкиваются с широким кругом проблем, связанных с сохранением и ускорением темпов роста. АБР выделит предсказуемое и существенное долгосрочное финансирование данной группе стран и станет их надежным партнером в поддержке структурных и системных реформ. Основными направлениями деятельности АБР в этих странах станет поддержка экологической и инклюзивной инфраструктуры, социальных услуг и социальной защиты, устойчивой урбанизации, структурных преобразований для повышения производительности и конкурентоспособности, реформ государственного сектора, развития частного сектора и мобилизации внутренних ресурсов. АБР также окажет содействие в реализации реформ государственных предприятий и расширении деятельности частного сектора путем привлечения частных инвесторов и коммерческих софинансирующих организаций. Особое внимание будет уделено странам, находящимся в уязвимых условиях из-за своего географического положения, в частности странах, расположенным в холмистой и горной местности. Эти страны сталкиваются с серьезными проблемами, вызванными изменением климата.

29. Страны с уровнем доходов выше среднего. Во многих странах с уровнем доходов выше среднего (UMIC) уровень жизни в целом повысился, при этом эти страны находятся на разном уровне экономического развития, отличаются социальными проблемами, доступом к рынкам капитала и институциональным потенциалом. АБР оптимизирует свою помощь этим странам в тех направлениях, в которых может принести наибольшую пользу, помогая им в расширении доступа к рынкам капитала, укреплении институтов и разработке демонстрационных проектов. АБР увеличит объем операций в частном секторе, в том числе для ГчП, окажет адресную поддержку реформам в финансовом секторе и государственных предприятиях, и в укреплении устойчивости стран к потрясениям. Совместно с самими странами АБР сместит акцент с увеличения объема кредитования на передачу опыта, передовой практики и инноваций, особенно в таких важных областях, как региональные общественные блага, изменение климата, урбанизация, РСИ и в решении таких возникающих социальных проблем, как старение населения. Для обмена такими знаниями АБР будет способствовать взаимодействию между самими развивающимися странами-членами.

30. Очаги нищеты и нестабильности на субнациональном уровне. В соответствии со своим видением обеспечения всеобщего охвата АБР будет уделять приоритетное внимание поддержке отстающих районов и очагов бедности в РСЧ, в том числе в странах с доходами выше среднего. Население в этих районах по-прежнему находится в состоянии хронической нищеты, зачастую вызванной нестабильностью и конфликтами на субнациональном уровне. АБР будет придерживаться адресного подхода к решению специфических задач в этих зонах, в том числе через оказание технической помощи (ТП) и упрощение бизнес-процессов.

31. Завершение оказания помощи. АБР продолжит использование действующей политики свертывания деятельности, не прекращая при этом оценивать ее эффективность. ${ }^{30}$ Процесс завершения регулярной помощи, включая анализ и оценку ключевых элементов по-

АБР. 2016 г. Тихоокеанский подход, 2016-2020 г2. Манила.

30 АБР. 1998 г. Политика свертывания операций АБР в РСЧ. Манила; и АБР. 2008 г. Обзор политики свертывания операций АБР за 1998 г. Манила. Политика завершения деятельности обеспечивает рамки классификации стран, исходя из доходов, доступности коммерческих потоков капитала на разумных условиях и уровне развития основных экономических и социальных институтов. 
литики свертывания деятельности, будет происходить в тесном сотрудничестве со страновыми партнерами. В течение переходного периода АБР сконцентрирует внимание на укреплении политики и институтов, необходимых для сбалансированного завершения операций АБР, поддержки глобальных и региональных товаров и услуг общественного потребления и разработки интеллектуальных решений. Данные приоритетные задачи будут отражены в ССП.

32. Диверсификация условий предоставления продуктов и инструментов. АБР проанализирует и обсудит с различными заинтересованными сторонами возможности углубления диверсификации финансовых условий. АБР рассмотрит различные варианты условий финансирования с тем, чтобы внедрить дифференцированные подходы и эффективно реализовать свои полномочия и внести максимальный вклад в развитие этих регионов.

33. Льготное финансирование. АБР намерен направить льготное финансирование беднейшим и наиболее уязвимым группам РСЧ, как в рамках кредитования из обычных основных ресурсов (ООР), так и гранта Азиатского фонда развития (АФР). Право на льготную помощь имеют многие страны в категориях FCAS и SIDS. АБР также рассмотрит возможности дополнительной помощи тем странам, для которых такая льготная помощь отменяется. Вопросы эффективного использования грантов АФР будут решаться совместно с донорами АФР. АБР также продолжит привлечение льготных внешних финансовых средств через целевые фонды, управляемые АБР, и софинансирование с двусторонними и многосторонними партнерами (пункты 87 и 89). 


\section{VI. ОПЕРАЦИОННЫЕ 7
ПРИОРИТЕТЫ}

34. Для осуществления Стратегии 2030 АБР сосредоточит свою деятельность на семи операционных приоритетных направлениях, описанных в пунктах 35-67. Эти задачи будут либо выполняться как отдельное направление, либо будут объединены с другими первоочередными задачами. Например, сокращение бедности, достижение более высокой степени интеграции, обеспечение гендерного равенства и реформы в системе управления будут включены, по мере необходимости, во все операции АБР. АБР будет оказывать помощь в решении этих задач в рамках операций в государственном и частном секторах, консультационных услуг и оказания помощи через передачу знаний.

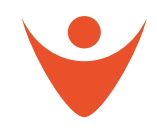

\section{А. Устранение сохраняющейся бедности и сокращение неравенства}

35. Повышенное внимание вопросам человеческого развития и социальной интеграции. Бедность представляет собой многоаспектную проблему. Несмотря на то, что в Азиатско-Тихоокеанском регионе достигнут колоссальный прогресс в снижении уровня бедности, связанной с доходами, еще больше усилий потребуется в преодолении не связанных с доходами аспектов нищеты и снижении уязвимости в городских и сельских районах; предстоит работа в продвижении социальной интеграции и развития, особенно для уязвимых групп, и наращивании потенциала сопротивляемости. Для того, чтобы все члены общества могли вносить вклад и пользоваться благами экономического роста, АБР окажет помощь РСЧ в следующих направлениях: (i) снижение неравенства в доступе к возможностям; (ii) содействие созданию качественных рабочих мест; (iii) расширение поддержки программ в сферах образования, здравоохранения и социальной защиты.

36. Создание качественных рабочих мест. АБР окажет содействие в создании достойных и производительных рабочих мест для поддержки всеобщего роста. Учитывая, что рабочие места, главным образом, открываются в частном секторе, АБР внесет вклад в улучшение бизнес среды в странах-членах для предпринимателей и бизнесменов, в том числе для малых и средних предприятий и субъектам инклюзивного бизнеса. АБР продолжит оказание помощи в повышении качества услуг для развития бизнеса и укрепления финансового сектора, в том числе инклюзивного финансирования. АБР будет также способствовать улучшению условий на рабочих местах, продвигая базовые нормы труда.

37. Повышение качества образования и обучения. АБР по-прежнему будет участвовать в совершенство-

\section{СЕМЬ ОПЕРАЦИОННЫХ ПРИОРИТЕТОВ СТРАТЕГИИ 2030}

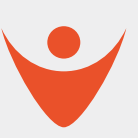

Устранение сохраняющейся бедности и сокращение неравенства

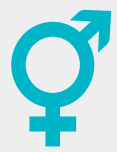

Ускорение прогресса на пути к гендерному равенству

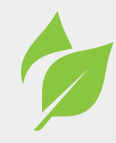

Борьба с последствиями изменения климата, формирование устойчивости к последствиям изменения климата и бедствий, повышение экологической устойчивости

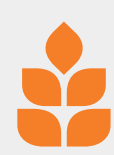

Стимулирование развития сельских территорий и продовольственная безопасность

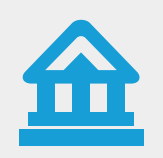

Укрепление управления и институционального потенциала
Содействие региональному сотрудничеству и интеграции

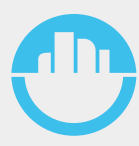

Города, пригодные для жизни

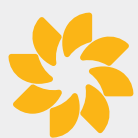


вании сферы образования как базовой потребности людей. АБР окажет помощь РСЧ в улучшении результатов всеобщего образования, системы трудоустройства и готовности выпускников к работе, а также в создании возможностей для обучения и профессиональной подготовки на протяжении всей жизни. Банк будет продвигать ИКТ в сферу образования и всеобщего обучения для всех, в любом месте и в любое время. АБР поможет повысить качество базовых навыков студентов, в том числе компьютерную грамотность и нетехнические навыки, а также техническое и профессиональное среднеспециальное образование и обучение. Банк окажет содействие в совершенствовании среднего и высшего образования, особенно в научных дисциплинах, технологиях, инженерном деле и математике, в частности, для студентов женского пола. АБР установит более тесные связи с промышленным сектором в реализации программ непрерывного образования и переподготовки, для того чтобы специалисты, находящиеся в середине своей карьеры, и работники более старшего возраста могли продолжать продуктивную трудовую деятельность.

38. Улучшение системы всеобщего здравоохранения. АБР продолжит оказывать поддержку РСЧ в обеспечении всеобщего охвата государственными и частными услугами здравоохранения и повышении их качества. Банк будет участвовать в реформах финансирования системы здравоохранения, в том числе систем страхования здоровья, для расширения доступа к качественным медицинским услугам для малоимущих слоев населения и сокращения их личных расходов. АБР будет работать над оптимизацией косвенных благ для здравоохранения за счет синергии с проектами Банка в транспортной сфере (дорожно-транспортная безопасность), в городском секторе («здоровые города»), водном секторе (безопасность воды), обеспечении санитарно-гигиеническими сооружениями (профилактика инфекционных заболеваний), и энергетике (низкий уровень выбросов углерода и загрязнения). АБР окажет помощь в противодействии обостряющимся проблемам, вызванным неинфекционными заболеваниями, а также в организации устойчивой и затратоэффективной системы ухода за престарелыми людьми. АБР также внесет вклад в продвижение инновационных и интеллектуальных систем оказания медицинских услуг.

39. Обеспечение социальной защиты нуждающихся. АБР продолжит проекты с РСЧ по консолидации систем социальной защиты и оказания социальных услуг, в первую очередь, путем совершенствования структуры и реализации программ выдачи социальных пособий, таких как адресные денежные пособия, пенсионные и условные денежные пособия, пенсионное и медицинское страхование, и программ рынка труда по приобретению трудовых навыков и переквалификации работников. Элементы социальной защиты будут внедрены в образовательные проекты (стипендиальные программы, в том числе для девушек; организация питания в школах, профессиональное обучение); в проекты в финансовом секторе, государственном управлении (социальное страхование и пенсионное обеспечение); здравоохранении (страхование здоровья); и городском секторе (создание инфраструктуры с учетом возрастных, гендерных особенностей и особенностей лиц с инвалидностью).

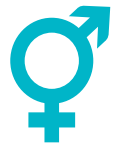

\section{В. Ускорение прогресса в обеспечении гендерного равенства}

40. Активизация поддержки достижению гендерного равенства. АБР окажет содействие РСЧ в ускорении прогресса в обеспечении гендерного равенства посредством (i) целенаправленных операций по расширению прав и возможностей женщин и девочек в таких сферах, как образование, охрана здоровья, охват финансовыми услугами и создание рабочих мест; (ii) внедрения гендерного подхода, который напрямую сокращает гендерные разрывы или предоставляет льготы женщинам и девочкам, например, проект по строительству дороги в сообществах, который открывает женщинам доступ к возможностям получения дохода, в сочетании с компонентом наращивания потенциала для помощи женщинам в улучшении их навыков; (iii) операций с учетом гендерных вопросов, предусматривающих ряд мер при разработке и реализации проектов и программ АБР, например меры по расширению возможностей трудоустройства для женщин в период строительства, эксплуатации и технического обслуживания объектов. Кроме того, в проектах, не входящих в список описанных в подпунктах (i)-(iii), также могут присутствовать положительные аспекты для жизни женщин и девочек. Например, проект по строительству электростанции не касается напрямую сокращения гендерных разрывов, поскольку речь идет о подаче электроэнергии в сеть; однако женщины получат выгоду от использования 
электроэнергии в плане сокращения дефицита времени и улучшения доступа к трудовым возможностям.

41. Целевые гендерные показатели. К 2030 году не менее $75 \%$ от числа совершенных операций АБР (в среднем за 3 года, включая как суверенные, так и несуверенные операции) будут способствовать продвижению гендерного равенства. ${ }^{31}$

42. Сферы деятельности. Помощь АБР будет сконцентрирована на пяти сферах деятельности: расширение экономических прав и возможностей женщин, гендерное равенство в человеческом развитии, гендерное равенство в принятии решений и лидерстве, сокращение дефицита времени у женщин и устойчивость женщин к внешним потрясениям.

43. Продвижение экономических прав и возможностей женщин. АБР будет уделять повышенное внимание созданию возможностей для занятости и предпринимательской деятельности женщин. Инфраструктурные проекты позволят максимально расширить доступ женщин к рынкам и квалифицированным рабочим местам. В рамках более углубленных программ технического и профессионального образования и обучения, АБР предоставит женщинам доступ к качественным рабочим местам в нетрадиционных и высокооплачиваемых секторах. АБР будет наращивать комплексную поддержку женщин-предпринимателей и МСП, возглавляемых женщинами, путем предоставления более эффективного доступа к финансам, внедрения новых технологий и содействия политическим и институциональным реформам.

44. Достижение гендерного равенства в человеческом развитии. Образовательные проекты будут нацелены на продвижение гендерного равенства в показателях завершения образования, результатов обучения и перехода от учебы к трудовой деятельности. АБР будет оказывать помощь молодым девушкам в получении образования в научной сфере, технологиях, технических дисциплинах и математике. Деятельность АБР в области здравоохранения и социальной защиты будет направлена на решение невыполненных задач по репродуктивным и другим медицинским потребностям женщин и девочек и на борьбу с гендерным насилием. Для облегчения обязанностей женщин по уходу за пожилыми членами семьи и удовлетворения различных нужд женщин пожилого возраста будут созданы специальные службы по уходу за пожилыми людьми.

45. Укрепление гендерного равенства в принятии решений и лидерстве. В ходе оказания помощи в осуществлении законодательных, институциональных и управленческих реформ АБР будут изучены способы устранения гендерных дискриминационных норм и расширения участия женщин в распределении общественных ресурсов и принятии решений, а также лидерства на всех уровнях.

46. Сокращение дефицита времени у женщин. АБР выделит инвестиции в такие инфраструктурные услуги, как водоснабжение и санитария, электрификация сельских районов, строительство дорог в сельской местности, внедрение экологически чистых кухонных плит и биогаза, а также технологий выращивания сельскохозяйственных культур и продуктов питания, для того чтобы снизить нагрузку и сократить время на обеспечение средствами к существованию и выполнение неоплачиваемой домашней работы и ухода. При проектировании городской и сельской инфраструктуры будут учитываться вопросы обеспечения безопасности и мобильности для женщин.

47. Укрепление устойчивости женщин к внешним потрясениям. АБР будет поддерживать РСЧ во внедрении гендерного подхода в противодействии последствиям изменения климата и стихийным бедствиям и открывать женщинам доступ к «зеленым» рабочим местам, технологиям, не причиняющим ущерб климату, и к участию в принятии решений, связанных с климатом. Для защиты женщин в малообеспеченных и уязвимых домохозяйствах от экономического, продовольственного и других кризисов АБР будет оказывать адресную социальную помощь и бюджетирование с учетом гендерных аспектов.

31 Объем операций, классифицированных как (i) и (ii) в п. 40, достигнет, по меньшей мере, 55\% от общего числа совершенных операций АБР (в среднем за 3 года, включая как суверенные, так и несуверенные операции). 


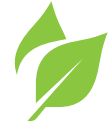

\section{С. Противодействие} последствиям изменения климата, подготовленности к ним, а также управление рисками стихийных бедствий и укрепление устойчивости окружающей среды

48. Расширение масштабов помощи в противодействии последствиям изменения климата, рискам стихийных бедствий и ухудшению состояния окружающей среды. АБР обеспечит, чтобы вопросы, связанные с изменением климата, рисками стихийных бедствий и охраной окружающей среды, полностью учитывались в операционных стратегиях, страновых программах, а также документации по разработке, реализации, мониторингу и оценке проектов. АБР будет способствовать улучшению доступа РСЧ к более экологичным и интеллектуальным технологиям, ускорению «зеленого» экономического роста и продолжит тщательное отслеживание проектов на предмет учета рисков, связанных с изменением климата и стихийными бедствиями.

49. Цели операций АБР в области борьбы с изменением климата. Основываясь на высоких результатах интеграции мер по смягчению последствий изменения климата и адаптации в структуру проектов, АБР обеспечит, что к 2030 году в 75\% от общего числа совершенных операций банка (в среднем за 3 года, включая как суверенные, так и несуверенные операции) будут предусмотрены аналогичные меры. В период с 2019 по 2030 годы объем финансирования проектов по борьбе с последствиями изменения климата из собственных ресурсов АБР достигнет в совокупности $\$ 80$ млрд. ${ }^{32}$

50. Снижение выбросов парниковых газов. АБР существенно расширяет поддержку мер по смягчению последствий изменения климата, отдавая приоритет инвестициям в развитие энергетики с низкими объемами выбросов парниковых газов, осуществляя стратегии, направленные на обеспечение устойчивого развития транспорта и городских перевозок, и стимулирования РСЧ к переходу к производству с низкими выбросами ПГ в соответствии с установленными на национальном уровне обязательствами в рамках Парижского соглаше- ния. Для достижения этих целей АБР будет избирательно использовать льготное финансирование, налаживать более тесные связи с частным сектором и поддерживать ГЧП. Для стимулирования инвестиций в проекты по смягчению последствий изменения климата АБР также облегчит доступ к углеродному финансированию на отечественных и/или международных рынках квот на эмиссию двуокиси углерода.

51. Обеспечение всестороннего подхода к повышению устойчивости к изменению климата и стихийным бедствиям. АБР окажет содействие РСЧ в разработке всесторонних подходов к адаптации и повышению устойчивости к изменению климата и стихийным бедствиям, включая принятие мер по управлению земельными ресурсами с учетом рисков, комплексному противодействию рискам наводнений, разработке инфраструктуры, устойчивой к климатическим изменениям и стихийным бедствиям, диверсификации источников жизнеобеспечения с учетом изменения климата в долгосрочной перспективе и усовершенствование систем раннего оповещения. АБР окажет помощь в реализации мер реагирования на стихийные бедствия, в том числе в более быстром восстановлении. Финансовая готовность РСЧ будет усилена за счет таких инструментов, как основанное на политике финансирование непредвиденных расходов и страхование на случай стихийных бедствий. ${ }^{33}$ АБР также будет участвовать во внедрении мер адаптации к изменению климата и противодействию стихийным бедствиям в планы и бюджеты РСЧ в области развития, и соответствующих мер по повышению потенциала и расширению доступа к знаниям.

52. Обеспечение экологической устойчивости. АБР будет: (i) вносить вклад в совершенствование организации охраны окружающей среды в РСЧ, в том числе в улучшение качества воздуха и воды; (iі) инвестировать в сохранение и восстановление природного капитала. Банк намерен усовершенствовать планирование и разработку проектов, принимая во внимание экологические задачи по предотвращению деградации экосистем и смягчению последствий загрязнения. Для этого АБР будет использовать различные подходы, в том числе платежи за экосистемные услуги, решения, основанные на природных явлениях (например, мангровые лесо-

32 Данные целевые показатели разработаны на основе определений и методологий, согласованных между многосторонними банками развития.

33 АБР выделил финансирование на случай непредвиденных стихийных бедствий в рамках программного кредитования островам Кука в 2016 году и Самоа, Тонга и Тувалу по региональной программе обеспечения готовности к стихийным бедствиям в 2017 году. 
насаждения против штормовых нагонов и повышения уровня моря), и инициативы на уровне сообществ.

53. Повышение внимания к решению комплекса вопросов водной, энергетической и продовольственной безопасности. АБР окажет содействие РСЧ в обеспечении общей водной безопасности за счет углубления понимания взаимосвязей и выбора между потребностями в продуктах питания и энергии на уровне проектов, секторов и стран. АБР расширит помощь в реализации мер комплексного управления водными ресурсами для справедливого, устойчивого и эффективного удовлетворения потребностей в воде. АБР также внесет вклад в (i) совершенствование способов сельскохозяйственной практики, в том числе в применение надежных технологий климатического моделирования и прогнозирования погоды; (ii) продвижение более водосберегающих технологий, таких как технологии использования солнечной и ветряной энергии; (iii) развитие энергоэффективного водоснабжения и санитарно-гигиенических сооружений.

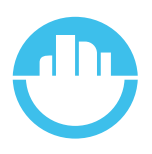

\section{D. Повышение удобства городов для проживания}

54. Предоставление комплексных решений. Содействуя строительству экологически чистых, конкурентных, устойчивых и инклюзивных городов, АБР будет осуществлять сквозные проекты по улучшению городской экологии, мобильности, продвижению гендерного равенства и экологической устойчивости. Проекты АБР будут сфокусированы на решении задач по водной безопасности и охраны окружающей среды для обеспечения доступных, безопасных, эффективных услуг водоснабжения и санитарно-гигиенических сооружений. Банк выделит средства на развитие таких систем общественного транспорта, как метрополитен и автобусное сообщение, соединенное с велосипедными и пешеходными дорожками с тем, чтобы люди, включая людей пожилого возраста и лиц с инвалидностью, могли легко пересаживаться с одного вида транспорта на другой. АБР намерен участвовать в создании соответствующих организаций, улучшении работы полиции и установлении благоприятных условий для повышения конкурентоспособности и продуктивности городов. Проекты, финансируемые АБР, будут нацелены на продвижение безопасной и здоровой городской среды для всех жителей города.
55. Помощь в финансировании городов. АБР будет оказывать помощь городам в привлечении новых и увеличении существующих источников финансирования, в том числе налогов на имущество, коммунальных платежей или административных сборов, а также прогнозируемых межбюджетных перечислений. Это поможет местным органам власти и коммунальным предприятиям в выпуске муниципальных облигаций или проектных облигаций, а также в изучении возможностей гчП.

56. Повышение качества инклюзивного городского планирования с участием всех заинтересованных сторон. АБР будет сотрудничать с городскими администрациями в приоритизации инвестиций и разработке комплексных планов развития города, исходя из местных потребностей. АБР будет изучать различия в потребностях всех, кто живет, работает и учится в городах в рамках совместных процессов с участием бизнеса, научно-исследовательских учреждений и ОГО. АБР, в партнерстве с заинтересованными сторонами и поставщиками услуг, улучшит секторальные планы, повысит институциональную кредитоспособность, разработку и реализацию проектов, устойчивость услуг.

57. Повышение устойчивости к изменению климата и управление рисками стихийных бедствий. Для повышения устойчивости городов, АБР будет способствовать интеграции решений по борьбе с изменениями климата и рисками стихийных бедствий в процессы городского планирования, что создаст возможности для обеспечения более качественной подготовленности к ним за счет улучшения систем раннего оповещения и планов реагирования на чрезвычайные ситуации для предотвращения смертельных случаев.

\section{Е. Содействие развитию сельского хозяйства и обеспечению продовольственной безопасности}

58. Улучшение рыночных связей и производственносбытовых сельскохозяйственных цепочек. Основным направлением усилий АБР станет улучшение сельских дорог, рыночной инфраструктуры и центров агрологистики для более тесной интеграции большего числа производителей, агропредприятий и потребителей в национальные, региональные и глобальные продовольственные системы. Сокращение послеуборочных 
потерь и увеличение добавочной стоимости в сельском хозяйстве будут способствовать росту доходов в сельской местности и укреплению продовольственной безопасности. АБР также поможет РСЧ улучшить связь и перемещения между сельскими и городскими регионами.

59. Повышение производительности сельского хозяйства и укрепление продовольственной безопасности. АБР окажет содействие РСЧ в повышении производительности сельского хозяйства и сокращении бедности за счет роста фермерских и нефермерских доходов. Банк будет способствовать применению передовых технологий, таких, как спутниковые приложения или приложения, управляемые с помощью беспилотного летательного аппарата, что повысит эффективность ирригации и обеспечит устойчивое использование земельных и водных ресурсов. АБР будет продвигать методы ведения сельского хозяйства, не причиняющие ущерб климату, включая возделывание сортов, устойчивых к наводнениям и засухам, и капельное орошение. АБР внесет вклад в улучшение стандартов управления природными ресурсами с помощью реализации проектов по мелиорации земель, восстановлению лесных массивов и управлению водосборными бассейнами для сокращения эрозии почвы и улучшения биоразнообразия.

60. Укрепление продовольственной безопасности. АБР окажет помощь РСЧ в разработке и реализации политики и стандартов, создании лабораторий по контролю качества, использовании ИКТ, улучшающих прослеживаемость происхождения продуктов питания и контроль их поставок. Банк примет участие в образовательных и обучающих программах, а также в информационно-разъяснительных мероприятиях на уровне сообществ, а также в инициативах по добровольному соблюдению установленных требований с вовлечением всех заинтересованных сторон - фермеров, представителей различных отраслей и потребителей.

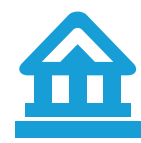

F. Совершенствование систем государственного управления и повышение институционального потенциала

61. Поддержка реформ государственного управления и вклад АБР в обеспечение финансовой стабильности. Надлежащее управление и прочный ин- ституциональный потенциал лежат в основе развития страны. АБР окажет помощь РСЧ в улучшении системы управления и создании благоприятных условий для устойчивого роста за счет повышения качества и укрепления потенциала для проведения политических реформ и ускорения развития частного сектора. АБР продолжит поддержку реформ системы государственных расходов, сбора доходов, в том числе налоговой системы и правоприменения, и рынков капитала через кредитование в поддержку реформ (PBL), кредитование, ориентированное на получение результатов, кредитование проектов и ТП. АБР окажет помощь в реализации государственных мер по искоренению коррупции и активизирует усилия по борьбе с отмыванием денег. Кроме того, Банк поддержит страны в присоединении к международным инициативам по прозрачности налогов. В тесном сотрудничестве с такими партнерами в области развития, как Международный валютный фонд, АБР внесет вклад в повышение сопротивляемости и подготовленности стран к экономическим потрясениям.

\section{2. Улучшение качества оказания государственных} услуг. Для повышения ответственности за предоставляемые услуги АБР будет содействовать эффективному, своевременному, свободному от коррупции оказанию государственных услуг. Для этой цели будут более активно внедряться ИКТ. Установлению финансовой стабильности, эффективной эксплуатации и обслуживанию инфраструктуры, оказанию иных услуг будет направлена поддержка АБР в реализации политических, законодательных и тарифных реформ. Банк будет участвовать в политических реформах, внесет вклад в совершенствование законодательства и тарифной политики. АБР будет сотрудничать с ГП и субнациональными организациями, которые более активно вовлечены в оказание государственных услуг, по наращиванию их потенциала в финансовом управлении и внутреннем регулировании, создавая им более благоприятные условия финансирования на коммерческих условиях.

\section{3. Укрепление потенциала и совершенствование} стандартов. АБР обеспечит экологические и социальные гарантии, будет придерживаться установленных стандартов проведения закупок и финансового управления, а также включит меры борьбы с коррупцией во всех свои проекты и программы. Это внесет вклад в соблюдение и улучшение стандартов в сообществе международного развития. АБР окажет помощь РСЧ в 
осуществлении реформ и создании страновых систем в этих областях. АБР также продолжит сотрудничество с исполнительными агентствами по усилению их потенциала в планировании, разработке, финансировании и реализации проектов АБР, в том числе в применении передовых технологий, сокращении расходов на срок службы, обеспечении финансовой жизнеспособности инвестиций и техническом обслуживании инфраструктурных активов.$$
\begin{aligned}
& \text { G. Содействие региональ- } \\
& \text { ному сотрудничеству и } \\
& \text { интеграции }
\end{aligned}
$$

64. Расширение коммуникационных возможностей и усиление конкурентоспособности. АБР улучшит взаимосвязи в регионе и укрепит конкурентоспособность РС4 за счет создания необходимой трансграничной инфраструктуры, что будет способствовать установлению политического диалога и координации усилий РС4 по преобразованию транспортных коридоров в торгово-экономические коридоры. Будут усилены мультимодальные транспортные соединения и энергетические связи в рамках всех субрегионов. Особое внимание будет уделено нуждам малых островных экономик и стран, не имеющих выхода к морю. АБР поддержит участие РСЧ в региональных и глобальных производственно-сбытовых цепочках. Деятельность АБР по расширению регионального сотрудничества и интеграции будет способствовать развитию сельскохозяйственной торговли и регионального туризма.

65. Развитие региональных общественных благ. АБР усилит помощь в обеспечении региональных общественных благ и реализации совместных действий для смягчения трансграничных рисков, связанных с изменением климата, загрязнением окружающей среды, энергетической и водной безопасностью, а также инфекционными и неинфекционными заболеваниями.
Для этого потребуется расширение регионального сотрудничества в таких областях, как финансирование мер противодействия рискам стихийных бедствий, освоение водосборных бассейнов, совершенствование политики в области здравоохранения, внедрение санитарных и фитосанитарных стандартов и установление карантина.

66. Укрепление сотрудничества в финансовом секторе. АБР будет укреплять сотрудничество в финансовом секторе путем развития региональных рынков облигаций, содействовать реализации общих рамок в финансовых правилах и надзоре, а также принятию мер по гармонизации трансграничных финансовых операций. АБР будет поддерживать общие подходы РСЧ для содействия региональной финансовой и экономической стабильности. АБР окажет помощь РСЧ в их участии в глобальных и региональных форумах по прозрачности налогов и мероприятиях по борьбе с отмыванием денег и финансированием антитеррористической деятельности.

67. Укрепление субрегиональных инициатив. С начала 1990-х годов АБР продвигает различные платформы субрегионального сотрудничества, такие как Программа субрегиона Большого Меконга (GMS), Программа Центральноазиатского регионального экономического сотрудничества (ЦАРЭС) и Программа субрегионального экономического сотрудничества Южной Азии (SASEC). АБР сотрудничает с Форумом тихоокеанских островов и АСЕАН. В рамках этих инициатив АБР расширит диалог по вопросам политики в таких областях, как производственно-сбытовые цепочки в сельском хозяйстве, образование, развитие навыков, рынки труда и медицинские услуги. Это будет способствовать обмену знаниями и сотрудничеству между субрегионами. АБР будет также сотрудничать с новыми международными и региональными инициативами. 


\section{VII. РАСШИРЕНИЕ ОПЕРАЦИЙ
В ЧАСТНОМ СЕКТОРЕ}

68. Расширение операций в частном секторе в поддержку семи операционных приоритетов АБР. АБР намерен углубить и расширить операции в частном секторе для успешной реализации семи операционных приоритетов. Именно в частном секторе РСЧ мобилизуются ресурсы для развития, открываются рабочие места, продвигаются инновации и эффективные технологии. Кроме того, частный сектор обеспечивает малоимущее население, женщин и уязвимые группы работой в основных отраслях экономики. Частный сектор также играет решающую роль в устранении серьезных рыночных пробелов, которые существует по всему Азиатско-Тихоокеанскому региону - начиная от краткосрочного финансирования торговли ${ }^{34}$ до среднесрочного финансирования МСП. ${ }^{35}$ Средства коммерческого сектора также необходимы для привлечения крупных сумм финансирования на строительство инфраструктуры в регионе. ${ }^{36}$

69. Целевые задачи в частном секторе. К 2024 году операции АБР в частном секторе достигнут в цифровом выражении одной трети операций АБР.

70. Двойной мандат АБР. Операции АБР в частном секторе будут способствовать устранению рыночных разрывов в регионе и активизировать развитие частного сектора для достижения ощутимых результатов в области развития. АБР будет стремиться к участию в решении задач в области развития как основной цели операций в частном секторе. Кроме того, Банк будет прилагать усилия по повышению прибыльности и коммерческой устойчивости, учитывая, что коммерческий успех соотносится с целями в области развития.

\section{1. Дополнительный вклад операций АБР в частном} секторе. Субъекты частного сектора предпочитают сотрудничать с такими финансовыми учреждениями в области развития, как АБР, так как они могут помочь в улучшении экологических, социальных и управленческих стандартов, выделяют финансовые средства, которые невозможно получить на рынке на приемлемых условиях; помогают улучшить дизайн проектов и повысить результаты в области развития; а также смягчить возможные риски. ${ }^{37}$ АБР будет стремиться максимально использовать эти преимущества. В дополнение к собственным финансовым средствам, АБР будет привлекать значительные суммы финансирования из внешних рынков. В рамках операций в частном секторе АБР намерен укреплять коммерческую устойчивость за счет высоких стандартов корпоративного управления, принципов честности и неподкупности, прозрачности и социальных, экологических гарантий и устранения рыночных сбоев без искажения рыночных механизмов.

АБР будет стремиться $\mathrm{K}$ достижению результатов в области развития как основной цели своей деятельности в частном секторе. Банк также намерен обеспечивать прибыльность и коммерческую устойчивость проектов, учитывая, что коммерческий успех соотносится с результатами в области развития.

\footnotetext{
34 А. Ди Каприо, К.Ким и С. Бек. 2017 г. Обзор пробелов в финансировании торговли, роста и занятости в 2017 году. Краткий обзор АБР №83. Манила: АБР.

35 П. Вандерберг, П. Шантапакдепонг и Н. Йшино. 2016 г. МСП в развивающихся странах Азии: новые подходы в устранении сбоев рынка. Токио: Институт АБР

36 АБР. 2017 г. Уовлетворение потребностей в инфраструктуре. Манила.

37 Международная финансовая корпорация. 2011 г. Международные финансовые организации и развитие в рамках частного сектора. Вашингтон
} 
72. Подготовка приемлемых для банков проектов в частном секторе. АБР окажет содействие в подготовке приемлемых для банков проектов, которые могут заинтересовать коммерческий сектор, посредством (i) анализа и подготовки проектов; (ii) привлечения большего объема капитала в компании, проекты и финансовые учреждения; (iii) обеспечения реализуемости проектов благодаря участию АБР, ТП, смешанного финансирования (совместно с льготными и иными трастовыми фондами), и других инструментов, таких, как резервные механизмы промежуточного финансирования; (iv) новых пилотных тестовых подходов, моделей и (v) улучшения структуры рисков проектов, используя дополнительное обеспечение кредитования АБР и продукты управления рисками.

73. Расширение охвата проектов в инфраструктуру и диверсификация в иные сектора. АБР по-прежнему будет способствовать участию частного сектора в инфраструктурных проектах в рамках корпоративного и проектного финансирования. В операциях в частном секторе будет увеличена помощь в следующих секторах: (i) возобновляемые источники энергии и другие отрасли инфраструктуры, такие, как инфраструктура, в особенности, городской транспорт; (ii) водные ресурсы, санитарно-гигиенические сооружения и финансирование в утилизацию отходов в поддержку создания городов, пригодных для жилья; (iii) новые коммуникационные технологии, предназначенные для жителей отдаленных районов. АБР расширит финансирование для агробизнеса, а также для социального сектора, в частности здравоохранения и образования, через частные предприятия, нацеленные на новые модели и доступные решения.
74. Расширение географического охвата. АБР будет наращивать операции в частном секторе на новых и пограничных рынках, в том числе на таких сложных рынках, как FCAS и SIDS. В ходе этого процесса АБР рассмотрит более мелкие сделки с потенциально высокими рисками и воздействием в области развития, включая инклюзивные бизнес-модели.

75. Расширение охвата финансовыми услугами. Операции АБР в частном секторе будут способствовать развитию финансового сектора в РСЧ для обеспечения доступности финансовых услуг, продвижения гендерного равенства; создания рабочих мест и обеспечения доступного жилья, страхования и сбережений. Для решения проблем краткосрочного финансирования АБР будет наращивать помощь банкам и небанковским финансовым учреждениям в РСЧ, чтобы повысить их потенциал, качество и охват, особенно среди малообеспеченных слоев населения. АБР расширит рамки различных программ финансового сектора, таких как финансирование торговли, цепи поставок и микрофинансирование.

76. Укрепление финансового сектора и рынков капитала. Для того чтобы устранить разрывы в средне- и долгосрочном финансировании, АБР (в рамках операций в частном секторе, а также кредитования экономических программ, ТП и развития потенциала) внесет вклад в развитие рынков облигаций, в частности, проектных облигаций, в том числе через прямое льготное кредитование и андеррайтинг. АБР будет стремиться к более тесному сотрудничеству с Инициативой АСЕАН +3 по Азиатским рынкам ценных бумаг и Фондом кредитных гарантий и инвестиций. ${ }^{38}$

\section{Операции АБР в частном секторе способствуют совершенствованию экологических, социальных стандартов и стандартов управления; обеспечивают финансирование, которое по приемлемым условиям отсутствует на рынке; помогают улучшить дизайн проектов и повысить результаты в области развития; а также смягчить предполагаемые риски.}

38 АСЕАН+3 включает 10 стран-членов АСЕАН, Японию, КНР и Республику Корею. 
77. Привлечение средств частного капитала для расширения охвата. АБР, учитывая свой огромный потенциал в оптимизации и мобилизации ресурсов, рассматривает фонды частного капитала как важный источник финансовой помощи. Основными направлениями операций АБР являются инфраструктура, финансовый сектор и изменение климата.

78. Расширение масштабов поддержки ГЧП. АБР будет наращивать помощь ГЧП посредством (i) содействия в информационно-разъяснительной работе по вопросам политики и развитию потенциала; (ii) помощи в создании благоприятных условий; (iii) оказания консультационных услуг по проведению сделок; (iv) помощи по разработке, структурированию и подготовке проектов; и (v) финансирования проектов в рамках суверенного и несуверенного кредитования. В роли разработчика проектов, АБР расширит масштабы консультационных услуг по сделкам с целью оказания содействия клиентам в создании структуры ГЧП и разработке четкого портфеля проектов на стадии разработки.
79. Применение подхода «Один АБР». Для того, чтобы принятые решения носили комплексный характер, АБР, в операциях с коммерческими структурами, будет опираться на свои проекты в государственном секторе. Операции в государственном секторе (кредитование как проектов, так и экономических программ и политических реформ) могут дополнять операции в частном секторе посредством создания более благоприятных условий для частного сектора и развития или подготовки ГП к коммерческому финансированию. Для предоставления РСЧ комплексного пакета решений, АБР обеспечит финансирование, ориентированное на государственный, частный сектора и ГЧП.

80. Усиление присутствия на местах. В условиях расширения географического охвата операций в частном секторе, АБР увеличит число сотрудников, отвечающих за это направление, в постоянных представительствах, а также повысит уровень подготовки и поддержки страновых директоров и персонала на местах. 


\section{VIII. СТИМУЛИРОВАНИЕ И ПРИВЛЕЧЕНИЕ ФИНАНСОВЫХ
СРЕДСТВ ДЛЯ РАЗВИТИЯ}

81. Установление прочных партнерских связей для более активного привлечения финансирования. Одной из важнейших задач, обозначенной в Стратегии 2030, является установление тесного сотрудничества с различными организациями, в том числе частными и государственными финансовыми учреждениями, а также традиционными и новыми партнерами в области развития, с целью мобилизации средств для суверен-

\section{Важнейшей задачей,}

обозначенной в Стратегии

2030, является установление

тесного сотрудничества с

различными организациями,

в том числе частными

и государственными

финансовыми учреждениями,

а также традиционными и

новыми партнерами в области

\section{развития.}

ных и несуверенных операций АБР. Ключевым показателем успеха АБР станет объем и качество ресурсов, изысканных в дополнение к своим собственным фондам финансирования.
82. Цели долгосрочного финансирования для операций в частном секторе. АБР ставит целью к 2030 году существенно приумножить объемы долгосрочного финансирования, чтобы на каждый доллар финансирования для проектов в частном секторе приходилось $\$ 2,50$ долгосрочного софинансирования. ${ }^{39}$

83. Привлечение финансовых средств из коммерческих источников. АБР будет предпринимать более активные усилия по мобилизации финансирования от частных софинансирующих организаций и инвесторов и стремиться к оптимизации собственных фондов финансирования. АБР будет изыскивать возможности для софинансирования, в частности, для инфраструктурных проектов, требующих крупных сумм финансовых средств. АБР будет предпринимать инициативы по дополнительному обеспечению займов, в том числе «В» займов, неполных гарантий рисков, неполных кредитных гарантий, передачи рисков АБР страховых компаниям, и механизмов распределения рисков в финансировании торговых операций для обеспечения потока частного капитала. Для внедрения инновационных решений Банк также будет использовать уникальное сочетание интеллектуальных финансовых решений частного сектора с тесными суверенными взаимосвязями.

84. Андеррайтинг и синдикация. АБР будет осуществлять андеррайтинг и впоследствии синдицировать крупные проекты, в том числе в местной валюте, для того чтобы обеспечить наличие финансовых средств для спонсоров проекта.

\section{5. Расширение партнерств с институциональными} инвесторами. Для того чтобы создать максимальные возможности для привлечения средств долгосрочных

\footnotetext{
Данный целевой показатель основан на соотношении общего долгосрочного софинансирования для операций частного сектора с общим объемом обязательных ООС для операций частного сектора за последние 3 года. Долгосрочное софинансирование включает в себя параллельные кредиты и собственный капитал, связанные с финансированием или консультационной деятельностью АБР, "В" займами, непокрытыми частями кредитов, гарантированных АБР, параллельными фондами и операционным резервом, возникающим в связи с механизмами передачи рисков. Это исключает финансирование торговли и снабжения. Общие использованные ООС исключает незадействованный операционный резерв, возникающий из-за механизмов передачи риска.
} 
частных фондов, АБР будет расширять партнерство с такими институциональными партнерами, как страховые компании и пенсионные фонды внутри и за пределами Азии. Основываясь на успехе ведущего фонда для инвестирования инфраструктуры частного сектора в Азии (в настоящее время выделяются инвестиции в акционерный капитал из Японии), АБР будет расширять платформы для управления фондами третьих сторон. Такие платформы будут функционировать на условиях софинансирования с операциями АБР в частном секторе, на основе процедур отбора сделок и их управлении.

86. Привлечение инвестиций через государственно-частные партнерства. АБР будет оказывать помощь странам в мобилизации более широкого спектра финансовых средств в рамках своей деятельности по расширению поддержки ГЧП (пункт 78). Содействие АБР в разработке, структурировании и подготовке приемлемых для банков проектов по ГЧП будет способствовать привлечению инвестиций частного сектора и интенсификации взаимодействия с ним. Для поддержки проектов ГЧП на этапе их подготовки, АБР будет привлекать Фонд по подготовке проектов в АзиатскоТихоокеанском регионе (в настоящее время его поддерживают Австралия, Канада, Япония) и другие фонды по разработке проектов.

\section{7. Мобилизация финансовых средств из льготных} источников. Привлечение льготного финансирования от двусторонних и многосторонних партнеров, включая Зеленый климатический фонд, Инвестиционные фонды противодействия изменению климата, Глобальный экологический фонд, остается важнейшим компонентом усилий АБР по мобилизации средств. Льготное финансирование является очень эффективным инструментом для финансирования проектов в РСЧ, обеспечивающее экономическую приемлемость долга в долгосрочной перспективе. Опираясь на положительные результаты управления льготными финансовыми средствами Фонда чистых технологий и Канадского климатического фонда для частного сектора в Азии,40 АБР будет использовать льготные средства выборочно, для того чтобы задействовать частные ресурсы для поддержки проектов с высокой степенью воздействия в области развития и потенциалом для демонстрации, воспроизведения и коммерческой устойчивости в соответствии с согласованными принципами. ${ }^{41}$

88. Расширение сотрудничества с новыми партнерами. АБР будет расширять партнерство с корпоративными и филантропическими фондами. Для увеличения финансирования проектов будут изучены инновационные способы. АБР будет укреплять сотрудничество с такими новыми многосторонними партнерами, как Азиатский банк инфраструктурных инвестиций и Новый банк развития.

89. Расширение финансирования из трастовых фондов АБР. АБР будет стремиться к увеличению грантов из односторонних или многосторонних целевых донорских фондов ${ }^{42}$, обеспечит эффективное и результативное использование этих средств для инвестиционных проектов, финансируемых за счет грантов, и ТП для развития потенциала, подготовки проектов и создания интеллектуальных решений. АБР, в тесном взаимодействии с вкладчиками фонда, реализует стратегический подход к продвижению инноваций, повысит качество

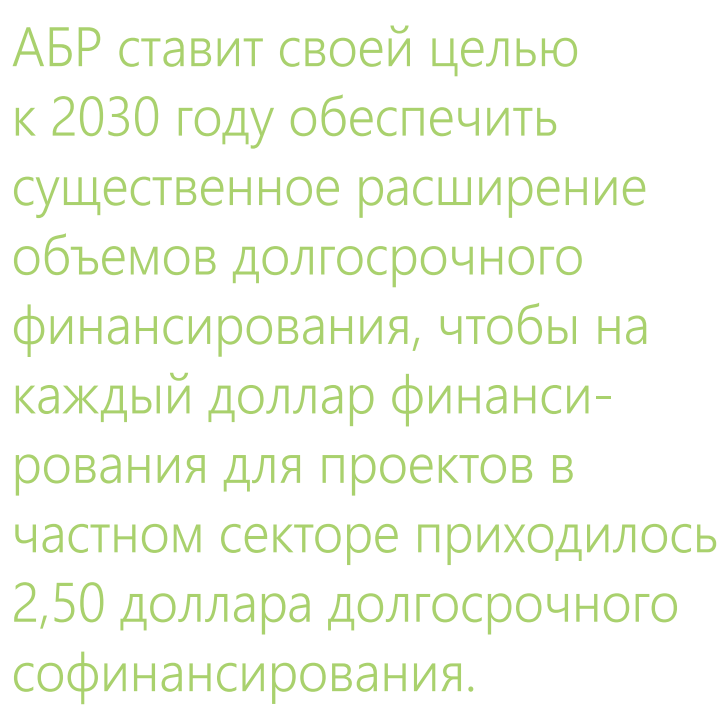

40 Это включает как Канадский климатический фонд для частного сектора в Азии, так и Канадский климатический фонд для частного сектора в Азии II.

41 Сводный отчет рабочей группы по финансовым институтам развития по смешанному льготному финансированию в октябре 2017 года был подготовлен группой, состоящей из экспертов Африканского банка развития, Азиатского банка развития, Азиатского банка инвестиций в инфраструктуру, Европейского банка реконструкции и развития, Европейского развития финансовыми институтами, Европейского инвестиционного банка, Межамериканской группы развития, Исламской корпорации развития частного сектора и Международной финансовой корпорации.

42 По состоянию на март 2017 года АБР управляет 49 целевыми фондами, из которых 28 являются фондами одного партнера, а 21 являются фондами с несколькими партнерами. Около 6\% официальных потоков софинансирования осуществляется через целевые фонды АБР. 
проектов и предоставит ценную помощь в осуществлении проекта.

90. Применение инновационных инструментов для собственного финансирования АБР. Для привлечения средств АБР продолжит, в рамках казначейских операций, использование таких инновационных инструментов, как «зеленые» и «водные» облигации, и бонды для экологически чистых видов энергии. Банк рассмотрит возможности использования долгосрочных облигаций Сингапура (SDG бондов) и Исламского финансирования для формирования средств для своих операций.

91. Улучшение бизнес среды для привлечения частных инвестиций. АБР окажет помощь РСЧ в создании благоприятных политических условий и качественной инфраструктуры, необходимой для привлечения инвестиций частного сектора, путем консультаций по вопросам политики, ТП, кредитования программ и реформ и проектов. Обновленный анализ критически значимых рыночных ограничений, возникших в ходе операций в частном секторе, выявит необходимость государственных мер в этих сферах.

\section{2. Активное привлечение отечественных ресурсов.} Инфраструктура и общественные услуги, финансируются, главным образом, за счет государственного бюджета. Для увеличения объема отечественных ресурсов АБР продолжит оказывать поддержку правительствам РСЧ в совершенствовании систем управления расходами и сбора доходов. АБР, совместно с другими партнерами в области развития, также будет способствовать укреплению прозрачности и регулированию долговыми обязательствами для обеспечения экономической приемлемости долга в долгосрочной перспективе. Помощь АБР развивающимся странам-членам в развитии финансовых учреждений и рынка капитала будет повышать эффективность региональных сбережений для прибыльного инвестирования. Расширение операций АБР в национальных валютах будет способствовать развитию соответствующих рынков и снизит риски. 


\section{IX. УЛУЧШЕНИЕ УСЛУГ

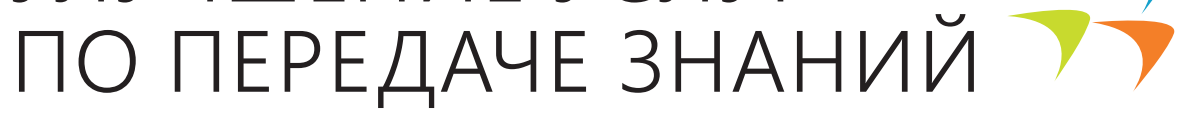

93. Деятельность АБР в области передачи знаний. Учитывая быстрые изменения в АзиатскоТихоокеанском регионе и тот факт, что большинство РСЧ достигли статуса стран со средним уровнем дохода, актуальность деятельности АБР будет в большей степени зависеть от реализации ее роли в качестве агентства по передаче знаний. Неявные знания АБР включены во все его проекты и программы. Явные (официально оформленные) знания предоставляются через различные продукты и услуги, такие как публикации, форумы и ТП. При наличии иных источников финансирования, клиенты, тем не менее, зачастую предпочитают обращаться к услугам АБР, поскольку АБР обеспечивает высокие стандарты в разработке и реализации проектов; передаче технологий и передовой практики; и, в более общем случае, передаче знаний, навыков и опыта, накопленного более чем за 50 лет сотрудничества с РСЧ.

94. Укрепление роли АБР как поставщика знаний. АБР намерен тесно сотрудничать с РСЧ по выявлению их потребностей и разрабатывать соответствующие интеллектуальные продукты и услуги. АБР будет также заранее планировать, создавать и предоставлять такие продукты знаний, в которых уже приняты во внимание возникающие и возможные потребности РСЧ. Банк будет стимулировать своих сотрудников внедрять наиболее передовые знания в процессы финансирования и наращивания институционального потенциала в ходе всего операционного цикла. АБР будет более качественно управлять неформализованными знаниями, в том числе опытом, полученным в ходе реализации проектов, и должным образом, в соответствии со стратегическими задачами по передаче знаний, организо- вывать ТП и размещать ресурсы. При разработке новых программ и проектов будут также использованы фактические материалы и заключения независимых оценок, а также оценок, проведенных самим АБР. На ежегодной основе будут пересматриваться ресурсы ТП для поддержки создания продуктов знаний. Для повышения качества таких продуктов будет поощряться сотрудничество секторальных и тематических групп с трастовыми фондами.

95. Расширение инициатив в проведении исследований. Знания АБР и исследования, основанные на фактических данных, повысят понимание важнейших сфер деятельности и помогут в разработке эффективной политики и реформ в РСЧ. АБР продолжит проведение исследований и будет предоставлять РСЧ компетентные рекомендации по вопросам политики. Исследовательские продукты АБР также внесут вклад в обсуждения глобального развития, демонстрируя перспективы Азиатско-Тихоокеанского региона.

96. Укрепление институционального потенциала развивающихся стран-членов. АБР будет продолжать развивать сотрудничество с правительствами РСЧ по улучшению их потенциала в решении вопросов в области развития и реализации проектов. Банк будет взаимодействовать с государственными агентствами, частным сектором, ОГО и экспертами в региональных и глобальных центрах знаний и учебных центрах, и содействовать сотрудничеству между странами внутри региона и за его пределами. В дополнение к поддержке создания потенциала и установления политического диалога в РСЧ, АБР будет использовать средства ТП для

Учитывая быстрые изменения в Азиатско-Тихоокеанском регионе

и тот факт, что большинство РСЧ достигли статуса стран со средним уровнем дохода, актуальность деятельности АБР будет в большей степени зависеть от реализации его роли в качестве организации по передаче знаний. 
пилотного тестирования инновационных подходов и решений в специфических областях или секторах, для того чтобы те подходы, которые оказались эффективными, распространялись в более широком масштабе.

97. Продвижение знаний в рамках АБР. АБР будет стимулировать создание продуктов и услуг знаний на уровне каждого отдела и их вклад в создание потенциала в областях их специализации. Секторальные и тематические группы АБР продолжат выполнять роли лидеров и координаторов в области передачи знаний. Структуры АБР, ответственные за проведение исследований, и Институт АБР по-прежнему будут создавать аналитическую базу для операций и консультаций по вопросам политики, предоставляемых АБР. Для оказания помощи РСЧ будут привлекаться собственные разработки АБР, такие, как проведение оценок, организация управления, ориентированного на получение результатов, борьба с коррупцией, соблюдение принципа честности и неподкупности, законодательство, закупки, аудит и внутренний контроль, управление рисками, казначейские операции и информационные технологии.
98. Расширение партнерств в области передачи знаний. АБР будет активно развивать и поощрять партнерства в области передачи знаний с двусторонними и многосторонними партнерами, аналитическими центрами, университетами, ОГО, фондами и частным сектором. Такие партнерства обеспечат платформы для экспериментального применения идей, изучения различных методов анализа важнейших вопросов в области развития, совместного формирования и обмена знаниями. С помощью таких партнерств будет организован сбор региональных данных в таких ключевых областях, как ЦУР, изменение климата, урбанизация и исследования. Эти знания далее будут использованы в операционной деятельности.

99. Распространение знаний. АБР будет стремиться к расширению доступа к знаниям, полученным в ходе операционной деятельности, исследований, политического диалога и усилий по развитию потенциала. Банк также расширит свои коммуникационные функции. АБР будет использовать как внутренние, так и внешние каналы коммуникации и цифровые технологии.

\section{АБР будет тесно сотрудничать с РСЧ по выявлению их потребностей и созданию наиболее актуальных продуктов и услуг по передаче знаний.}




\section{X. АБР СТРЕМИТСЯ СТАТЬ СИЛЬНЕЕ, ЛУЧШЕ И БЫСТРЕЕ $७$}

100. Обеспечение надежной ресурсной базы. После слияния кредитных операций Азиатского фонда развития с балансом ООС, АБР располагает солидной базой капитала для поддержки операций, предусмотренных в Стратегии 2030. Для поддержания благоприятной позиции капитала АБР будет продолжать оптимизировать внутренние административные и операционные расходы и изучать способы обеспечения органического роста капитала. Для оптимизации своего капитала и укрепления финансовой устойчивости АБР будет регулярно анализировать рамки достаточности капитала и ценообразование; использовать механизмы передачи риска, такие как перестрахование, гарантии и переуступка рисков АБР; и максимально использовать сторонние коммерческие и льготные фонды и совместное финансирование. По мере необходимости, могут быть рассмотрены возможности увеличения капитала в целом или в частных случаях, исходя из потребностей в финансировании и при поддержке акционеров.

101. Укрепление человеческих ресурсов. АБР будет расширять кадровый резерв, привлекать высококвалифицированных экспертов в новых приоритетных областях и оптимизировать три принципа - скорость, качество и прозрачность - процессов найма. Банк будет инвестировать в обучение и профессиональное развитие персонала (в том числе в проведении операций, приобретении лидерских навыков, освоении цифровых технологий и управлении изменениями). Образовательные и обучающие программы будут способствовать углублению понимания и взаимодействию специалистов, участвующих в реализации операций в государственном и частном секторах. Система АБР по оценке эффективности работы будет способствовать росту мотивации персонала и созданию благоприятной высокопроизводительной рабочей атмосферы. Благодаря улучшению навыков, обмену знаниями и продвижению инноваций, специалисты АБР станут более мобильными, в том числе в разработке краткосрочных проектов; активизируется ротация сотрудников между департаментами, постоянными представительствами и головным офисом. АБР привержен цели диверсификации рабочей силы, в том числе достижению гендерного баланса и созданию уважительной рабочей среды для всех.

102. Сохранение сильного присутствия в странах. Будут укреплены позиции постоянных представительств в странах, как единого центра для партнеров в стране для всех продуктов и услуг АБР, что, благодаря эффективному сочетанию навыков в секторальных, тематических, суверенных и несуверенных операциях, основанных на потребностях конкретных стран, повысит технический потенциал представительств АБР. АБР усилит свое присутствие во время нестабильных и конфликтных ситуаций и в малых островных развивающихся государствах. Постоянные представительства будут тесно сотрудничать с секторальными и тематическими группами по повышению качества взаимодействия со страновыми партнерами, их своевременному консультированию по политическим вопросам и способствовать эффективному осуществлению проектов.

103. Совершенствование продуктов и инструментов АБР. АБР будет и далее улучшать качество и расширять спектр своих продуктов и инструментов для оказания индивидуальной поддержки клиентам из государственного и частного секторов. В суверенных операциях АБР продолжит оказание помощи РСЧ в выборе наиболее эффективных способов в достижении целей развития. Несмотря на то, что проектные займы, как правило, представляют собой наиболее распространенный способ финансирования и эффективны для обмена ноу-хау и экспертизы при разработке и реализации проектов, в ряде РСЧ более активно стали применяться кредитование в поддержку реформ (PBL) и кредитование, ориентированное на получение результатов. Учитывая, что потребности клиентов становятся все более разнообразными и сложными, АБР будет эффективно использовать вышеуказанные два инструмента. В рамках операций в частном секторе АБР будет продолжать совершенствовать и расширять свою продукцию и условия, включая инвестиции в акционерный капитал и продукты повышения кредитоспособности. Банк будет предоставлять финансовые решения в национальной валюте как для суверенных, так и для несуверенных операций. 
104. Модернизация бизнес-процессов и повышение операционной эффективности. АБР нацелен на кардинальную модернизацию бизнес-процессов за счет использования преимуществ имеющихся в наличии технологий. Банк будет и впредь повышать операционную эффективность и сокращать сроки подготовки и администрирования займов, грантов и ТП, без ущерба качеству и при строгом соблюдении принципа честности и неподкупности. АБР будет оптимизировать бизнес-процессы по оказанию консультационных услуг, пилотного тестирования и покупки оборудования и услуг для эксплуатации и обслуживания. АБР будет осуществлять четкую программу укрепления организационной устойчивости для обеспечения непрерывности функционирования и создания потенциала кризисного реагирования.

105. Содействие цифровой трансформации. Для модернизации бизнес-процессов АБР будет стремиться к оптимальному использованию новейших безопасных информационных продуктов, технологических систем и цифровых процессов для повышения эффективности, результативности и устойчивости своей деятельности. Цифровая трансформация АБР будет способствовать обеспечению доступа к данным по всем аспектам деятельности и администрированию в реальном режиме. Банк создаст цифровые платформы, которые облегчат создание широкого спектра интеллектуальных продуктов и услуг и сделает их доступными для партнеров и заинтересованных сторон. Кроме того, АБР окажет содействие во внедрении инновационных финансовых продуктов и в целом будет развивать культуру нововведений и оперативного реагирования на меняющиеся потребности клиентов.

106. Обеспечение своевременных и качественных закупок. АБР будет продолжать содействовать совершенствованию систем закупок с использованием подхода, основанного на соблюдении принципов и оценке рисков. ${ }^{43}$ Банк будет оказывать поддержку РСЧ в укреплении потенциала в проведении закупок. Он также будет поддерживать закупки высокоуровневых технологий, а также более активно использовать закупочные системы софинансирующих сторон. Процедуры закупок, предназначенные для конкретных целей, будут проводиться для инновационных проектов с использованием передовых технологий для широкого спектра продуктов и услуг в области знаний АБР.

\section{7. Расширение использования страновых систем.}

АБР будет стремиться к более активному использованию страновых систем в операциях с государственным сектором, для того чтобы снизить вероятность задержек в реализации проектов, сократить операционные издержки, усилить национальную ответственность и укрепить государственные учреждения и системы в РСЧ. АБР окажет содействие в использовании страновых систем закупок, государственного финансового управления, экологических и социальных гарантий. Поскольку страновые системы в РСЧ отличаются своими особенностями и сильными сторонами, для обеспечения соблюдения стандартов АБР будет использоваться контекстно-ориентированный подход.

108. Усиление сотрудничества с организациями гражданского общества. АБР будет учитывать уникальные преимущества ОГО, такие как местное присутствие и специализированные знания. Банк будет изучать возможности для более активного вовлечения ОГО в разработку и реализацию проектов, поддерживаемых АБР. Особое внимание будет уделяться операциям, в которых используются подходы, основанные на широком участии населения, с тем, чтобы целенаправленно охватить бедные и уязвимые группы, мобилизовать женщин и молодежь, и осуществлять мониторинг проектных мероприятий и результатов. АБР также будет консультироваться с ОГО при пересмотре основных направлений политики АБР.

109. Реализация стратегии. Осуществление Стратегии 2030 начнется сразу после ее одобрения Советом директоров. 44 Принимая во внимание перспективы Стратегии и стремительно меняющиеся потребности РСЧ в области развития, от АБР потребуются гибкость и оперативность в ходе реализации новой стратегии. АБР будет систематически планировать, предпринимать действия и осуществлять мониторинг достижения результатов, используя для этого различные каналы. Вопервых, в отдельных планах деятельности будут сформулированы стратегические цели, конкретные области ра-

43 АБР. 2017 г. Повышение эффективности проектов АБР через реформы в закупках. Манила.

44 Стратегия 2030 заменит Стратегию 2020 и среднесрочный обзор Стратегии 2020. 
боты, подходы и общие квалификационные требования для каждого операционного приоритета. Во-вторых, в ССП будут дополнительно уточнены первоочередные задачи и конкретизированы операции АБР, исходя из страновых условий, вызовов и потребностей данной РСЧ и потенциала повышения добавочной стоимости в рамках возможностей АБР и имеющихся ресурсов для реализации четкого круга задач. В-третьих, будет улучшена рабочая программа и бюджетные рамки для того, чтобы обеспечить согласованность годового рабочего плана и имеющихся ресурсов с операционными приоритетами.
110. Мониторинг результатов. Для мониторинга и оценки хода осуществления проектов будет разработана матрица корпоративных результатов, которая будет включать общие и целевые показатели по приоритетам Стратегии 2030. Первоначальная матрица результатов по Стратегии 2030 будет охватывать 6-летний период с 2019 по 2024 годы. После завершения 6-летнего периода матрица корпоративных результатов будет обновлена. Банк продолжит подготовку ежегодных отчетов по институциональной деятельности, используя матрицу результатов ОЭР. 


\section{ХІ. ОДИН АБР}

111. Подход «Один АБР». Для того чтобы следовать намеченному в Стратегии 2030 курсу, АБР усилит подход «Один АБР», объединив опыт и знания в различных сферах своей деятельности. Специалисты, работающие в проектах АБР в частном и государственном секторах, будут активно участвовать в планировании операций, общими усилиями выявляя и устраняя факторы, сдерживающие развитие, а также в подготовке проектов. АБР разработает, при поддержке отраслевых и тематических групп и с использованием передовых технологий, комплексные решения. Благодаря научным исследованиям будет улучшена аналитическая база для проектов и усилено взаимодействие с клиентами по стратегическим вопросам. Такой подход будет реализован с помощью повышения мобильности персонала и его мотивации в рамках оценки эффективности работы.

Для того чтобы следовать намеченному в Стратегии 2030 курсу, АБР усилит подход «Один АБР», объединив опыт и знания в различных сферах своей деятельности. 


\section{ПРИЛОЖЕНИЕ: \\ ОБЗОР ОПЕРАЦИЙ АБР \\ И РЕЗЮМЕ ИТОГОВ \\ КОНСУЛЬТАЦИОННЫХ СОВЕЩАНИЙ}

1. Азиатский банк развития (АБР) отслеживает ход реализации Стратегии 2020. ${ }^{1}$ В 2014 году проведен обзор промежуточных итогов Стратегии 2020 и разработан план действий в отношении новых вызовов в регионе. ${ }^{2}$ Эффективность развития измеряется по матрице корпоративных результатов. Деятельность АБР оценивается департаментом независимой оценки (ДНО) на различных уровнях (т.е., на уровне проектов, по секторам, тематическим направлениям, страновым программам и организационной политике). В ходе разработки Стратегии 2030 были собраны и проанализированы мнения различных заинтересованных сторон в странах-членах АБР, как в рамках региона, так и за его пределами, а также членов советов и специалистов АБР.

\section{А. Среднесрочный обзор Стратегии 2020}

2. В среднесрочном обзоре анализируются уроки, полученные в процессе реализации Стратегии 2020, и оцениваются существующие и новые вызовы, стоящие перед развивающимися странами-членами АБР (РСЧ). В среднесрочном обзоре стратегии подчеркивается, что АБР выстраивает свою операционную деятельность четко в соответствии с тремя стратегическими направлениями Стратегии 2020: инклюзивный экономический рост, экологически устойчивое развитие и региональная интеграция. В период с 2008 по 2012 годы более 80\% операций АБР были сконцентрированы в основных областях Стратегии 2020 с большим объемом операций в инфраструктурном секторе. Обзор также выявил, что АБР необходимо укреплять институциональный потенциал, в том числе улучшать навыки персонала и оптимизировать бизнес-процессы. По итогам среднесрочного обзора сделан вывод, что Стратегия 2020 сохраняет свою действенность и актуальность в отно- шении стратегических направлений. Однако, регион претерпевает быстрые изменения и это значит, что АБР тоже необходимо меняться. По результатам анализов и оценки в среднесрочном обзоре обозначена 10-шаговая программа для усиления будущих стратегических направлений АБР до 2020 года и повышения оперативности реагирования на изменяющуюся обстановку.

i. Снижение уровня бедности и инклюзивный экономический рост. Искореняя крайнюю нищету, ослабляя уязвимость и неравенство через продвижение инклюзивного экономического роста, АБР продолжит реализацию своего видения региона, свободного от бедности. АБР намерен повысить объем помощи в сферах здравоохранения и образования и предоставит дополнительные ресурсы уязвимым РСЧ с низким уровнем доходов и затронутых конфликтами.

ii. Охрана окружающей среды и изменение климата. В ответ на серьезные экологические проблемы, существующие в регионе, АБР увеличит поддержку мер адаптации к изменению климата, не прекращая при этом оказывать помощь в смягчении последствий климатических явлений в рамках проектов по внедрению экологически чистых источников энергии и энергоэффективности, а также внедрения устойчивого транспорта.

iii. Региональное сотрудничество и интеграция. АБР планирует расширить региональные связи и производственно-сбытовые цепочки через поддержку инвестиций в трансграничную инфраструктуру и соединение экономических

АБР. 2008 г. Стратегия 2020: Долгосрочные стратегические рамки АБР, 2008-2020 г2. Манила.

АБР. 2014 г. Среднесрочный обзор Стратегии 2020: Решение задач меняющегося Азиатско-Тихоокеанского региона. Манила; и АБР. 2014 г. Среднесрочный обзор Стратегии 2020: План действий. Манила. 
узловых центров для увеличения товарооборота и расширения коммерческих возможностей.

iv. Развитие инфраструктуры. Инфраструктура останется основным направлением операций АБР. АБР будет стремиться к улучшению показателей инфраструктурных проектов посредством более активного вклада в развитие сектора, внедрения технических разработок и повышение эффективности работы. Банк будет способствовать обеспечению устойчивости инфраструктуры за счет повышения качества технического обслуживания и эксплуатации.

v. Страны со средним уровнем дохода. Учитывая, что к 2020 году подавляющее большинство РСЧ достигнет статуса стран со средним уровнем дохода, для надлежащего и своевременного реагирования на меняющиеся потребности этих стран в области развития, АБР необходимо совершенствовать свои стратегические подходы.

vi. Развитие частного сектора и операций. АБР будет целенаправленно расширять помощь частному сектору, осуществляя для него до 50\% ежегодных операций до 2020 года, в том числе до 25\% операций из ежегодных обычных основных ресурсов. Такой вклад АБР будет способствовать улучшению бизнес среды в РСЧ и более эффективно привлекать частные инвестиции. Являясь финансирующей организацией, АБР при этом станет более активно заниматься разработкой проектов.

vii. Интеллектуальные решения. Для налаживания совместной работы по разработке интеллектуальных решений все департаменты АБР будут использовать подход «Один АБР». Функции координатора операций АБР и установления партнерства и организации обсуждений с РСЧ возможных решений в области знаний возлагаются на постоянные представительства. Для обеспечения актуальности усилий АБР в разработке интеллектуальных решений, профильные сообщества АБР станут более активно вовлекаться в подготовку проектов и создание соответствующих продуктов знаний. ${ }^{3}$ viii. Финансовые ресурсы и партнерства. Регион по-прежнему нуждается в больших объемах финансировании в области развития. Деятельность АБР потеряет свою актуальность при отсутствии адекватных финансовых средств. АБР увеличит потенциал кредитования, в том числе за счет возможного объединения средств Азиатского фонда развития с обычными основными средствами на балансе.

iх. Рациональное использование средств АБР. АБР нацелен на повышение эффективности и результативности своих операций. Для более качественного осуществления проектов будут реформированы и рационализированы бизнеспроцессы, в особенности, в системе проведения закупок. Для измерения и мониторинга показателей эффективности более планомерно будут применяться оценочные матрицы на организационном, страновом и проектном уровнях.

х. Обеспечение готовности к новым вызовам. АБР обеспечит комплексное развитие навыков своих работников, внедрение стимулов и институциональных механизмов с тем, чтобы стать более динамичной, гибкой и инновационной организацией. Мандат и полномочия постоянных представительств будут расширены.

\section{В. Обзор эффективности развития}

3. Недавно проведенные оценки эффективности деятельности АБР показали, что Банком предприняты важные шаги в достижении своей цели - стать более сильной, эффективной и динамичной организацией. Для усиления позиции и согласования своей деятельности со стратегическими задачами АБР уверенно следует по пути реализации видения, обозначенного в Стратегии 2020, принимая во внимание итоги среднесрочного обзора. Операции в поддержку экологической устойчивости, наряду с мерами смягчения и адаптации к последствиям изменения климата, развитием частного сектора и системы государственного управления, а также наращиванием потенциала, постепенно расширяют свои масштабы. АБР также неуклонно продвигается в выполнении задач по региональному сотрудничеству и

Профильные сообщества были преобразованы в секторальные и тематические группы. 
интеграции (РСИ), а также реализации стратегии достижения гендерного равенства. Однако, ввиду существенного увеличения обязательств, упускаются из внимания цели по привлечению софинансирования. ${ }^{4}$ Результаты проектов в области образования, здравоохранения, социальной защиты носят неоднозначный характер. Установление целевых показателей в сферах образования и здравоохранения в среднесрочном обзоре усилило фокус на этих направлениях. ${ }^{5}$ Однако, данные показывают, что для достижения намеченных целей до 2020 года, следует увеличить финансирование операций в области здравоохранения.

4. В отношении повышения качества следует отметить, что в большей мере улучшилось качество работы на начальном этапе проекта. В завершенных проектах высокие показатели эффективности были достигнуты в вопросах продвижения гендерного равенства и в проектах оказания технической помощи. В целом, положительные результаты на этапе завершения, как правило, отмечаются в суверенных операциях. Более сложно повысить устойчивость и улучшить показатели для несуверенных операций. АБР по-прежнему сталкивается со сложностями в повышении оперативности своей деятельности. Несмотря на то, что удалось сократить сроки между получением одобрения и присуждением контракта, АБР предстоит более активная работа по устранению задержек проектов, сокращению сроков внутренней обработки и процедур проведения закупок.

\section{С. Обзоры Департамента независимой оценки}

5. Департамент независимой оценки осуществил оценку трех стратегических программ Стратегии 2020 (инклюзивный экономический рост, экологически устойчивый рост и региональное сотрудничество и интеграция) и пяти факторов изменений (развитие частного сектора, операции в частном секторе, надлежащая организация управления и развитие потенциала, гендерное равенство, интеллектуальные решения и партнерства).
6. По оценке Департамента независимой оценки не было уделено должного внимания таким значимым для инклюзивного экономического роста, но не обозначенным в рамках Стратегии 2020 в качестве ключевых задач оперативной деятельности, как здравоохранение, образование и социальная защита. ДНО подверг сомнению обоснованность разделения на основные и вторичные операционные направления и предложил отказаться от такой практики. Избирательный подход к операциям необходим, однако, следует адаптировать этот подход с учетом страновых и географических особенностей и не руководствоваться секторальными целями в направлении «сверху-вниз». Более активная поддержка социального сектора, а также сельского хозяйства, гендерного равенства и продовольственной безопасности, усилит общий вклад АБР в развитие инклюзивной экономики. В отношении экологически устойчивого роста, несмотря на то, что доля проектов АБР, которые были определены как проекты, способствующие устойчивой охране окружающей среды, в период с 2013 по 2015 годы увеличилась, около одной трети этих проектов, согласно оценке, принесли лишь минимальные или неощутимые экологические выгоды. ДНО также рекомендует АБР расширить масштабы помощи странам-членам в борьбе с изменениями климата и обеспечении экологически устойчивого роста. Что касается РСИ, то ДНО определил вклад АБР в этой области как достойный высокой оценки. АБР, в первую очередь, оказывал помощь в создании физической сообщаемости за счет развития трансграничной инфраструктуры и теперь, по мнению ДНО, следует уделить больше внимания обеспечению региональных общественных благ, повышению производительности, укреплению конкурентоспособности участвующих экономик, смягчению уязвимости региона и ликвидации субрегионального неравенства.

7. В отношении факторов развития, по заключению Департамента независимой оценки, АБР необходимо улучшить внутреннюю координацию и механизмы поддержки развития частного сектора. Требуется приложить больше усилий, для того чтобы АБР стал функционировать как единая организация. Необходимо в

\footnotetext{
4 АБР принял на себя обязательство расширить поддержку РСИ, для того чтобы достичь к 2020 году, как минимум, 30\% объема общих операций. Число совершенных суверенных операций по содействию внедрению гендерного подхода в процентах от общего количества совершенных суверенных операций должно было составить 50\%. Общее годовое прямое софинансирование должно было превысить сумму автономного проектного финансирования АБР.

Финансирование образования и здравоохранения должно было достичь 6\%-10\% и 3\%-5\% от общего финансирования АБР, соответственно.
} 
отраслевых стратегиях, страновых стратегиях партнерства и в соответствующих матрицах достижения результатов более тесно увязать суверенные и несуверенные операции. АБР следует сосредоточить внимание на сокращении числа отмененных проектов, увеличении объема и качества инвестиций в уставной капитал других компаний и расширение синдицирования и гарантий. Более активное участие АБР в отраслевых, коммерческих, промышленных проектах и в сфере агробизнеса будет способствовать повышению стоимостной ценности деятельности АБР. ДНО особо выделил потенциально преобразующее воздействие надлежащей организации государственного управления для достижения результатов в области развития и рекомендовал АБР продолжать работу в этом направлении, несмотря на относительно слабые показатели успешного завершения проектов в этой области.

8. В Стратегии 2020 предусмотрено существенное расширение поддержки продвижения гендерного равенства. Для выполнения этой задачи АБР следует усовершенствовать систему разделения женщин на категории, а также улучшить сбор исходных данных в разбивке по полу. ДНО также подчеркнул необходимость более систематического документирования результатов продвижения гендерного равенства на страновом и проектном уровнях. АБР следует придерживаться более предметного и комплексного подхода в операциях, связанных с передачей знаний и установлением партнерств, на основе бизнес-модели, основным принципом которой является оптимизация передачи знаний и финансирования. ДНО также рекомендует расширять базу экспертных знаний и укреплять сотрудничество между региональными департаментами и проектами в частном и государственном секторах. Опыт АБР в создании партнерств по обмену знаниями в тематических и секторальных областях носит неоднозначный характер. Проекты на условиях софинансирования были значительно более успешными, чем те, которые финансировались только АБР. ДНО также предлагает АБР внести изменения в организационные обязанности, системы и правила для улучшения управления партнерскими связями.

9. Департамент независимой оценки рекомендует АБР в Стратегии 2030 в большей степени нацелиться на качественный рост (вместо расширения масштабов), включая взаимное усиление трех следующих направлений: социальная и географическая интеграция, экологическая устойчивость и РСИ как основных направлений стратегического интереса и главной экономической ценности. Развивающиеся страны-члены АБР, несмотря на то, что большинство из них стало или станет странами со средним уровнем доходов, представляют собой разнородную группу с большими различиями в уровнях дохода, структуре валового внутреннего продукта, показателях бедности, продовольственной безопасности и институционального потенциала. Некоторые факторы, которые почти два десятилетия способствовали беспрецедентному росту и сокращению бедности в Азиатско-Тихоокеанском регионе, в настоящее время теряют свою силу. Более того, ситуация усугубляется изза мегатенденций изменения климата, экологических потрясений, урбанизации и старения населения, а также стремительного развития технологий. В связи с этим, АБР следует разработать индивидуальные решения путем оптимизации финансирования и передачи знаний и применения в своей деятельности более целевого и комплексного подхода. ${ }^{6}$

\section{D. Консультации с заинтересованными сторонами}

10. Для изучения мнений и перспектив различных заинтересованных сторон в отношении Стратегии 2030, АБР, начиная с октября 2015 года, проводит углубленные консультации в регионе и за его пределами, а также внутри страны. В них уже приняли участие представители различных организаций, в том числе центральных и местных органов власти, организаций гражданского общества, аналитических центров, научных и учебных заведений и коммерческих структур.

11. Консультации с развивающимися странами-членами. Заинтересованные стороны в РСЧ предлагают расширить формулировку видения АБР, и включить в нее инклюзивный рост, устойчивое развитие и наращивание сопротивляемости экономическим и экологическим угрозам. Многие из них определили инфраструктуру и РСИ как успешные направления в деятельности АБР и отметили необходимость укрепления потенциала в социальных секторах. По их мнению, необходимо

6 АБР. 2017 г. Знания, финансы и качество роста: оченочная перспектива Стратегии 2030. Манила. 
также расширить помощь ГЧП. Требуется увеличить масштабы кредитования АБР, поскольку многие задачи РСЧ в области развития еще не решены, более того, по-прежнему имеют место финансовые трудности, в том числе в странах со средним уровнем дохода. Заинтересованные стороны в РСЧ подчеркнули необходимость АБР поддерживать страновую направленность и применять комплексный подход. Они обратились к АБР с просьбой оказать содействие в выполнении национальных обязательств и помочь в противодействии последствиям изменения климата и рискам стихийных бедствий, в том числе посредством инновационных финансовых механизмов. Они призвали АБР упорядочить бизнес-процессы для сокращения операционных расходов и повышения эффективности и подчеркнули необходимость содействия в обмене опытом и знаниями в области развития между странами региона.

12. Консультации в развитых странах. Заинтересованные стороны в развитых странах поддерживают цели АБР, намеченные в ответ на новые вызовы в области развития и учитывающие потребности различных клиентов. Они признают потенциал АБР в привлечении финансовых средств, стимулировании политического диалога и разработке интеллектуальных решений. Они рекомендует АБР расширить масштабы своих операций, в том числе в частном секторе и ГЧП, и децентрализовать свою деятельность за счет увеличения штата в представительствах на местах. Они также предложили АБР продолжать работу по защите уязвимых групп населения, в том числе детей, лиц с инвалидностью, малообеспеченных городских жителей, и подчеркнули важность более активных действий, способствующих упрощению процесса обмена знаниями между менее развитыми странами и более продвинутыми экономиками в регионе. Присутствие АБР в странах с доходами выше среднего должно быть избирательным, и сосредоточено, главным образом, в тех странах, в которых АБР может принести максимальную пользу.

13. Иные группы. Донорские организации Азиатского фонда развития подчеркнули, что АБР следует уделить первостепенное внимание сокращению масшта- бов нищеты и инклюзивному росту. Они хотели бы получить больше поддержки для развития частного сектора, управления государственным сектором и регионального сотрудничества. Они поддерживают дифференцированный подход к клиентам, обозначенный в стратегии, включая разработку четкой стратегии для стран с доходами выше среднего. Заинтересованные стороны в странах, в которых АБР завершил свою деятельность, отмечают роль АБР в качестве организации по привлечению и мобилизации частного финансирования для развития и потенциал АБР в содействии региональному сотрудничеству и передаче знаний и технологий. Они также отметили важную роль АБР в устранении огромных пробелов в инфраструктуре в регионе. Специалисты АБР подчеркнули необходимость сосредоточить внимание на части стратегии 2030 «как» для ответа на вопрос «что». Они выразили поддержку межсекторальному сотрудничеству, поскольку страны-клиенты сталкиваются с более сложными проблемами, требующими межсекторальной координации. Они также признали необходимость переподготовки и расширения полномочий сотрудников АБР, учитывая усиление акцента на межсекторальных и тематических вопросах.

14. Круглые столы с видными учеными в области развития. В 2017 году проведены четыре круглых стола с известными экспертами в Лондоне, Маниле, Токио и Вашингтоне, которые поделились своим пониманием роли АБР в Азиатско-Тихоокеанском регионе в период до 2030 года. Они заострили внимание на необходимости искоренения бедности и неравенства, противодействия последствиям изменения климата, укрепления регионального сотрудничества, внедрения технологий и интеллектуальных решений в проекты, взаимодействия со странами с доходами выше среднего и наращивания притока финансов из частного сектора. Некоторые эксперты рекомендовали АБР выходить за рамки инфраструктурных проектов и в большей степени сосредоточиться на социальных секторах. 


\section{Эксперты, принимавшие участие в круглых столах по Стратегии 2030}

\begin{tabular}{|c|c|}
\hline Имя эксперта & Должность, организация \\
\hline Масуд Ахмед & Президент Центра глобального развития, Вашингтон, США \\
\hline Баронесс Валери Амос & Директор Лондонского университета SOAS, Великобритания \\
\hline Шинджи Асанума & $\begin{array}{l}\text { Приглашенный профессор, Азиатская государственная политическая программа, Школа } \\
\text { международной и государственной политики, Университет Хитоцубаши, Токио, Япония }\end{array}$ \\
\hline Каушик Басу & $\begin{array}{l}\text { Профессор экономики и международных исследований кафедры К. Маркса, Корнельский } \\
\text { университет, Нью-Йорк, США }\end{array}$ \\
\hline Рашеда Чаудхари & Исполнительный директор, Кампания за народное образование, Бангладеш \\
\hline Лорд Мегхнад Десаи & $\begin{array}{l}\text { Председатель консультативного совета при Официальном форуме монетарных и финансовых } \\
\text { учреждений, Лондон, Великобритания }\end{array}$ \\
\hline Синнамон Дорнсайф & $\begin{array}{l}\text { Старший консультант Программы международного развития и старший научный сотрудник } \\
\text { Института внешней политики, Университета Джона Хопкинса, Вашингтон, США }\end{array}$ \\
\hline Ник Дайер & $\begin{array}{l}\text { Генеральный директор политических и глобальных программ, Департамент международного } \\
\text { развития, Лондон, Великобритания }\end{array}$ \\
\hline Гэнг Фэн & $\begin{array}{l}\text { Директор Национального института экономических исследований, Председатель Китайского } \\
\text { фонда реформ, Пекин, Китайская Народная Республика }\end{array}$ \\
\hline Нобухико Фува & Профессор, выпускник Высшей школы государственной политики, Университет Токио, Япония \\
\hline Хайхонг Гао & $\begin{array}{l}\text { Профессор и директор Центра исследований международного финансирования, Институт } \\
\text { мировой экономики и политики, Китайская академия социальных наук, Пекин, КНР }\end{array}$ \\
\hline Ника Гилаури & Учредитель и управляющий партнер, ООО «Реформатика»; и бывший Премьер-министр Грузии \\
\hline Мэгги Горман Велес & $\begin{array}{l}\text { Директор, эксперт в области политики и оценки, Центр исследований международного } \\
\text { развития, Оттава, Канада }\end{array}$ \\
\hline $\begin{array}{l}\text { К. Лоуренс Гринвуд, } \\
\text { младший }\end{array}$ & Президент, Японское общество Северной Калифорнии, США \\
\hline Маргарет Хьюбер & $\begin{array}{l}\text { Президент, Канадский международный совет, отделение национального капитала, Оттава, } \\
\text { Канада }\end{array}$ \\
\hline Йипинг Хуанг & $\begin{array}{l}\text { Jin Guang Профессор кафедры экономики и заместитель декана Национальной школы развития } \\
\text { и Директор института цифрового финансирования, Пекинский университет, Пекин, КНР }\end{array}$ \\
\hline Джанг Таик Хьюн & $\begin{array}{l}\text { Президент, Корейский институт международной экономической политики, Седжон-Си, } \\
\text { Республика Корея }\end{array}$ \\
\hline Шада Ислам & $\begin{array}{l}\text { Директор по Европе и геополитике, организация «Friends of Europe» (Друзья Европы), Брюссель, } \\
\text { Бельгия }\end{array}$ \\
\hline Шигео Катсу & Президент, Назарбаев университет, Астана, Казахстан \\
\hline Хоми Карас & $\begin{array}{l}\text { Старший научный сотрудник и заместитель директора Глобальной программы по экономике и } \\
\text { развитию, Брукингский институт, Вашингтон, США }\end{array}$ \\
\hline Кэрол Анне Киду & $\begin{array}{l}\text { Бывший министр развития общин и член законодательного органа законов, Папуа-Новая } \\
\text { Гвинея }\end{array}$ \\
\hline Хисаки Коно & Доцент, Высшая школа экономики, Киотский университет, Киото, Япония \\
\hline Раджив Кумар & $\begin{array}{l}\text { Старший научный сотрудник Центра политических исследований, Нью-Дели, Индия; и Канцлер, } \\
\text { Институт экономики и политики Гохале, Махараштра, Индия }\end{array}$ \\
\hline Тае-Шин Квон & $\begin{array}{l}\text { Заместитель председателя и Главный исполнительный директор Федерации корейских отраслей } \\
\text { промышленности, Сеул, Республика Корея }\end{array}$ \\
\hline Йоханнес Линн & $\begin{array}{l}\text { Старший научный сотрудник, Глобальная экономика и программа развития, Брукингский } \\
\text { институт, Вашингтон, США }\end{array}$ \\
\hline Марк Милай & Вице-Президент по политике, Деловой Совет США-АСЕАН, Вашингтон, США \\
\hline Виктор Муринде & $\begin{array}{l}\text { Профессор, Школа финансов и менеджмента, Университет Лондона SOAS, Лондон, } \\
\text { Великобритания }\end{array}$ \\
\hline Адорасьон Наварро & $\begin{array}{l}\text { Заместитель секретаря и Руководитель регионального развития, Национальный орган } \\
\text { экономического развития, Пасиг, Филиппины }\end{array}$ \\
\hline
\end{tabular}




\begin{tabular}{|c|c|}
\hline Имя эксперта & Должность, организация \\
\hline Кэрол Ньюмен & Председатель, Trinity International Development Initiative, Тринити колледж, Дублин, Ирландия \\
\hline Юмико Нода & Партнер, Глава партнерства по инфраструктуре и ГЧП, ТОО PwC Advisory, Токио, Япония \\
\hline Аннмари О'Киффе & $\begin{array}{l}\text { Приглашенный член, Научно-исследовательская организация - Lowy Institute, Сидней, } \\
\text { Австралия }\end{array}$ \\
\hline Изуми Охно & Профессор, выпускник Национального института политических исследований, Токио, Япония \\
\hline Маайке Окано-Хейджманс & $\begin{array}{l}\text { Старший научный сотрудник, Институт международных отношений Clingendael, Гаага, } \\
\text { Нидерланды }\end{array}$ \\
\hline 3ao Oo & Исполнительный директор, Центр экономического и социального развития, Янгон, Myanmar \\
\hline Джанко Отани & Профессор, Высшая школа гуманитарных наук, Университет Осака, Осака, Япония \\
\hline Кейджиро Отсука & Профессор, Магистр экономики, Университет Кобе, Кобе, Япония \\
\hline Мари Элка Пангетсу & Профессор международной экономики, Университет Индонезии, Джакарта, Индонезия \\
\hline Мэтт Рид & Главный Исполнительный Директор, Фонд Ага Хан, Великобритания, Лондон \\
\hline Дэн Ранде & $\begin{array}{l}\text { Председатель William A. Schreyer и Директор проекта по повышению благосостояния и } \\
\text { развитию, Центр стратегических и международных исследований, Вашингтон, США }\end{array}$ \\
\hline Юрий Сато & $\begin{array}{l}\text { Исполнительный вице-президент, Институт развивающихся экономик, Японская организация } \\
\text { по внешней торговле, Тиба, Япония }\end{array}$ \\
\hline Мартин Сигер & Главный исполнительный директор и Президент, Lahmeyer International GmbH, Гессен, Германия \\
\hline Ютаро Шинтаку & Директор и корпоративный советник, Terumo Corporation, Токио, Япония \\
\hline Сьюзан Сискел & $\begin{array}{l}\text { Исполнительный вице-президент и Главный операционный директор, Фонд Азии, } \\
\text { Сан-Франциско, США }\end{array}$ \\
\hline Тетсуши Сонобе & $\begin{array}{l}\text { Вице-президент; Председатель комитета докторантуры; Директор программы глобального } \\
\text { управления GRIPS (G-куб); профессор, Национальный институт политических исследований, } \\
\text { Токио, Япония }\end{array}$ \\
\hline Паола Субаччи & $\begin{array}{l}\text { Директор по исследованиям в области международной экономики, Аналитический центр } \\
\text { «Chatham House», Лондон, Великобритания }\end{array}$ \\
\hline Акира Суэхиро & $\begin{array}{l}\text { Декан и профессор, факультет международных социальных наук, Университет Гакусюин, Токио, } \\
\text { Япония }\end{array}$ \\
\hline Айя Сузуки & $\begin{array}{l}\text { Приглашенный профессор, Департамент международных исследований, Выпускник Школы } \\
\text { передовых технологий, Университет Токио, Тиба, Япония }\end{array}$ \\
\hline Ричард Тьютен & $\begin{array}{l}\text { Руководитель отдела международных финансовых организаций, Департамент международного } \\
\text { развития, Лондон, Великобритания }\end{array}$ \\
\hline Ясуюки Тодо & $\begin{array}{l}\text { Профессор, Выпускник Школы экономики, факультет политических наук и экономики, } \\
\text { Университет Васэда, Токио, Япония }\end{array}$ \\
\hline Аноте Тонг & Экс-Президент, Кирибати \\
\hline Кеничи Уэда & Доцент кафедры экономики, Университет Токио, Токио, Япония \\
\hline Колоне Вааи & Со-управляющий директор и главный консультант, KVAConsult Ltd, Апиа, Самоа \\
\hline Крис Вермонт & Главный исполнительный директор, Управляющая компания «Гарант», Лондон, Великобритания \\
\hline Ульрих Вольц & Начальник отдела экономики, Лондонский университет, Лондон, Великобритания \\
\hline Йошихиро Ватанабе & Профессор, Высший Институт Предпринимательских Исследований, Ниигата, Япония \\
\hline Беатрис Ведер ди Мауро & $\begin{array}{l}\text { Профессор экономики и кафедры экономической политики и международной макроэкономики, } \\
\text { Майнцский университет, Майнц, Германия }\end{array}$ \\
\hline Олин Уэтингтон & Член-нерезидент, Атлантический совет, Вашингтон, США \\
\hline Джеральд Райт & $\begin{array}{l}\text { Старший научный сотрудник, Школа международных отношений Нормана Патерсона, } \\
\text { Университет Карлетона, Оттава, Канада }\end{array}$ \\
\hline Даниэль Зеликов & Руководитель, Международная группа государственного сектора, J.P. Morgan, Вашингтон, США \\
\hline Вейинг Занг & $\begin{array}{l}\text { Председатель, Профессор экономики, Национальная школа развития, Пекинский университет, } \\
\text { Пекин, КНР }\end{array}$ \\
\hline
\end{tabular}

ACЕАН = Ассоциация государств Юго-Восточной Азии, США = Соединенные Штаты Америки.

Источник: Азиатский банк развития. 

www.adb.org/strategy2030

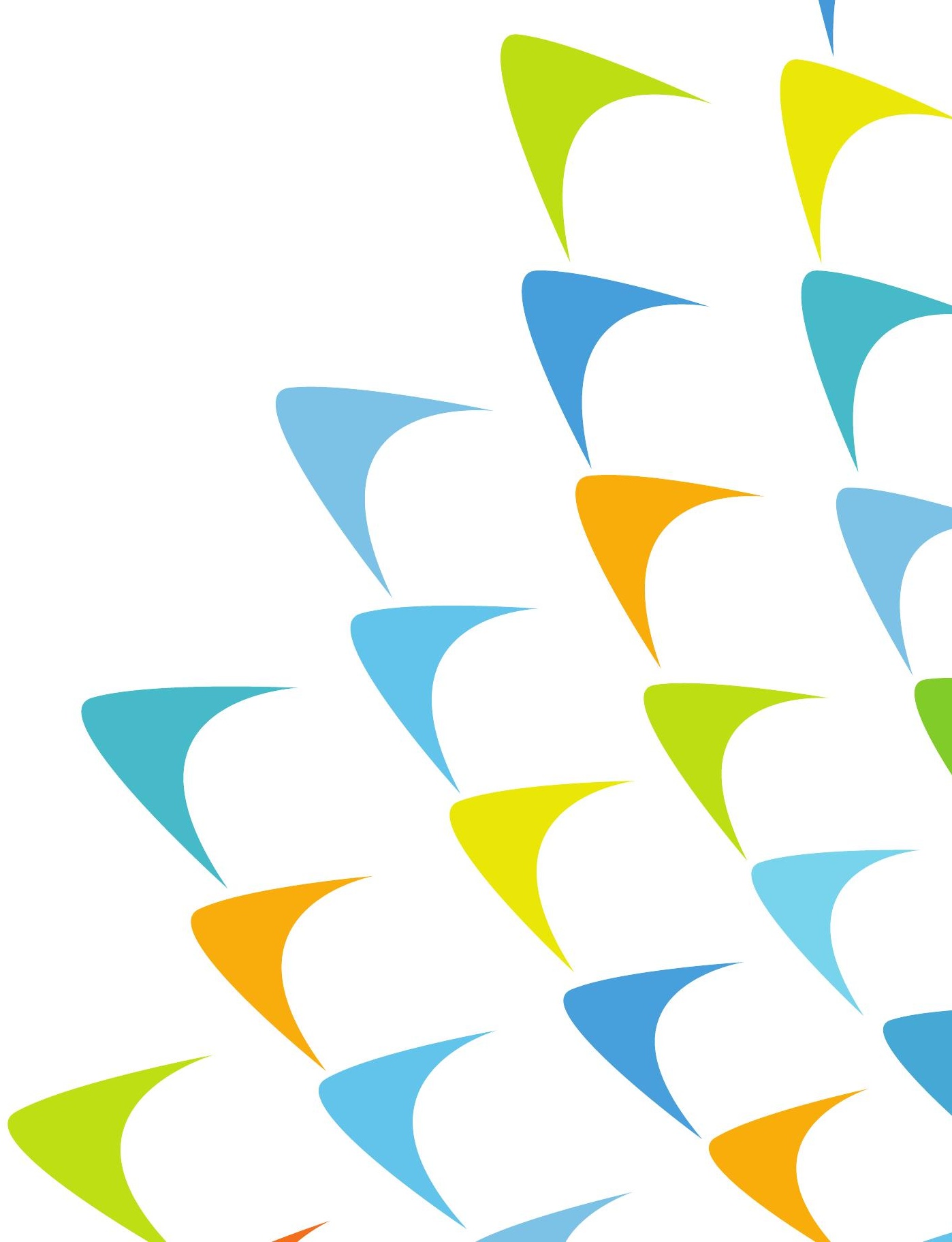




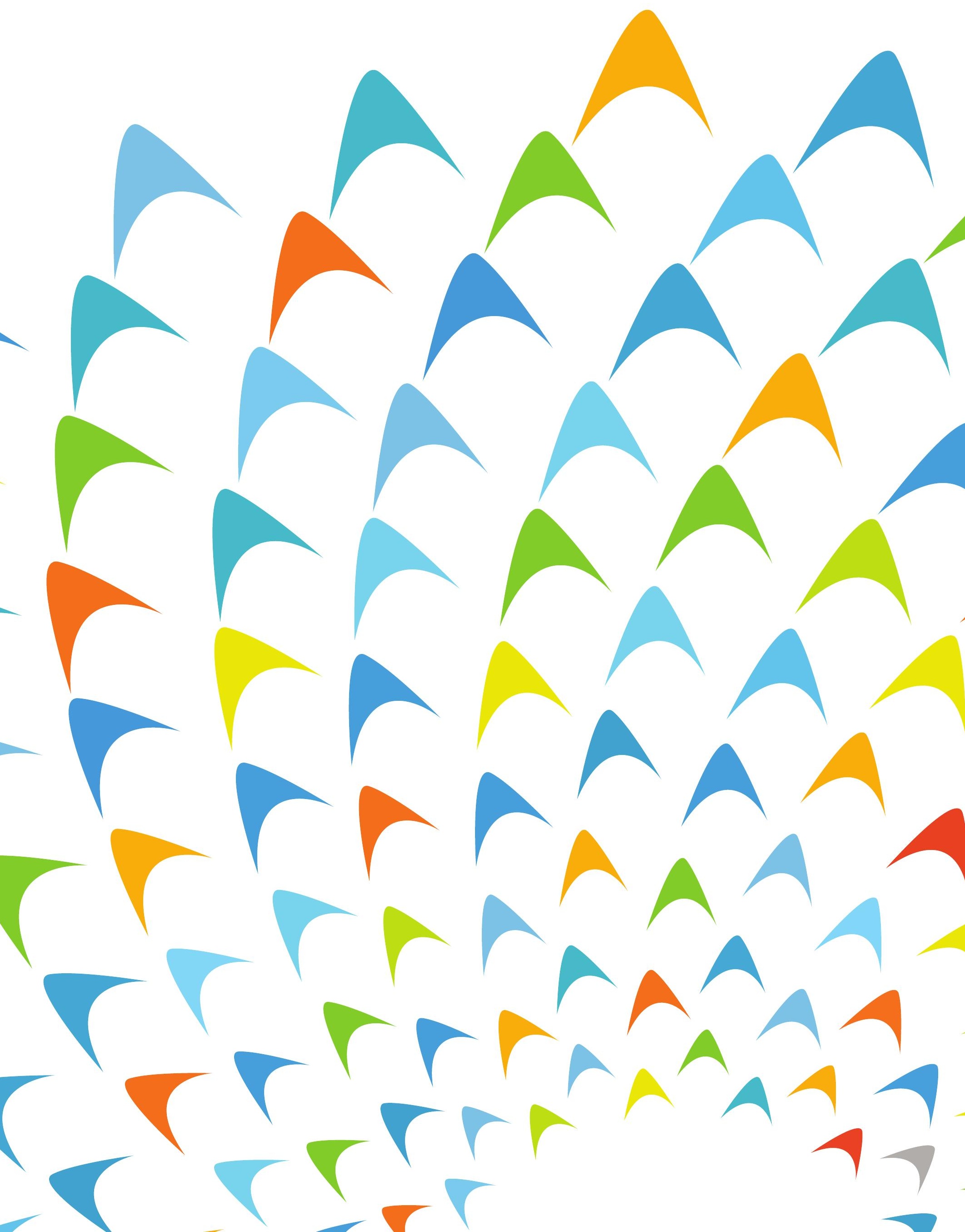




\section{Стратегия 2030}

Создание процветающего, инклюзивного, жизнестойкого и устойчивого Азиатско-Тихоокеанского региона

За последние 50 лет в Азиатско-Тихоокеанском регионе достигнут большой прогресс в сокращении бедности и ускорении экономического роста. Ключевую роль в существенной трансформации региона играет Азиатский банк развития (АБР). АБР подтверждает свою приверженность оказанию помощи региону в последующие 15 лет. В Стратегии до 2030 года обозначен курс деятельности АБР в ответ на меняющиеся потребности региона. В Стратегии до 2030 года АБР расширяет свое видение создания процветающего, инклюзивного, жизнестойкого и устойчивого Азиатско-Тихоокеанского региона, не прекращая при этом усилий по искоренению крайней нищеты.

\section{Об Азиатском банке развития}

АБР привержен цели достижения процветающего, инклюзивного, жизнестойкого и устойчивого АзиатскоТихоокеанского региона, постоянно прилагая при этом усилия, направленные на искоренение крайней нищеты. Созданный в 1966 году, АБР объединяет 67 стран-членов, из которых 48 находятся в самом регионе. Основными инструментами банка в оказании содействия развивающимся странам-членам являются диалог по вопросам политики, займы, инвестиции в акционерный капитал, гарантии, гранты и техническая помощь.

$\mathrm{ADB}$

\section{ASIAN DEVELOPMENT BANK}

6 ADB Avenue, Mandaluyong City

1550 Metro Manila, Philippines

www.adb.org

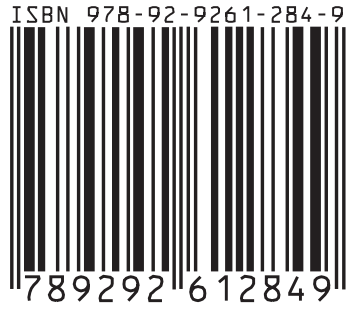

